Volume 114

Issue 1 Dickinson Law Review - Volume 114,

2009-2010

6-1-2009

\title{
Freedom from the Press: Why the Federal Propaganda Prohibition Act of 2005 is a Good Idea
}

Stanislav Getmanenko

Follow this and additional works at: https://ideas.dickinsonlaw.psu.edu/dlra

\section{Recommended Citation}

Stanislav Getmanenko, Freedom from the Press: Why the Federal Propaganda Prohibition Act of 2005 is a Good Idea, 114 Dick. L. REV. 251 (2009).

Available at: https://ideas.dickinsonlaw.psu.edu/dlra/vol114/iss1/6

This Article is brought to you for free and open access by the Law Reviews at Dickinson Law IDEAS. It has been accepted for inclusion in Dickinson Law Review by an authorized editor of Dickinson Law IDEAS. For more information, please contactlja10@psu.edu. 


\section{Comments}

\section{Freedom from the Press: Why the Federal Propaganda Prohibition Act of 2005 is a Good Idea}

\section{Stanislav Getmanenko*}

Table of Contents

I. INTRODUCTION......................................................... 252

II. HISTORICAL BACKGROUND AND THE FIRST AMENDMENT ....... 255

A. Technology: The Catalyst of Change............................. 255

B. From a Bludgeon to the First Amendment....................... 258

C. From the First Amendment to the Manufacture of Consent

III. HISTORICAL AND MODERN-DAY USE OF PROPAGANDA IN THE UNITED STATES

A. The Central Role of the Media in the Delivery of

Propaganda

B. Historical Examples of Propaganda in the United States .. 264

1. Pre-ratification 264

* J.D. Candidate 2010, The Dickinson School of Law of the Pennsylvania State University; B.S. 2006, Brigham Young University. I would like to thank all those who contributed their precious time to edit this piece. As always, I dedicate my efforts to my family and loved ones, who very well may disagree with the opinions set forth here. 
2. Alien and Sedition Acts ................................................265

3. Endorsement of Political Candidates by the Media, an Example of Political and Social Antique ..................266

4. Stealth Propaganda...........................................................268

5. Classification of Some Information by the Government and Propagation of Other Information, The Fake News 270

6. Modern-day Developments, the Internet, and Usergenerated Content

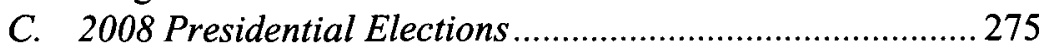

1. Widely-recognized Bias in the Traditional Media .........275

2. "Sarah Palin is a Member of Alaska Independence Party"-Anonymous on A1 of The New York Times....277

IV. PRESENT REGULATORY FRAMEWORK 278

A. FARA: An Antiquated but Effectual Legislative Response 278

B. The Federal Communications Commission and the Internet Age. 280

1. Spectrum Scarcity and Content Regulation ...................280

2. FCC and Government-funded Speech ..........................282

3. Network Neutrality: Spectrum Scarcity Revisited.......283

C. The Supreme Court: A Sentinel of the First Amendment?

1. Full Disclosure 285

2. Supreme Court Puzzle: Constitutionality of Government-funded Speech.

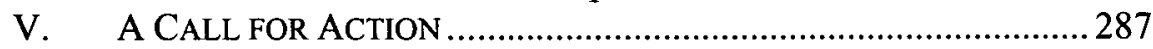

A. The Insufficiency of Media Self-restraints 287

B. Failure to Pass the Federal Propaganda Prohibition Act of 2005

C. Can the FCC Fill the Void? 290

D. What's on the Horizon? 291

VI. CONCLUSION 291

\section{INTRODUCTION}

This Comment reviews First Amendment freedom of the press through the prism of technological change brought about in the last decade. When the First Amendment ${ }^{1}$ secured fundamental human

1. U.S. CONST. amend. I. 
liberties in 1791 , its main purpose was to oppose tyranny. ${ }^{2}$ The passage of the First Amendment was a logical extension and the culmination of the pilgrims' escape from state-sponsored persecution. At that time, the First Amendment amounted to the triumph of liberal thought which granted people their long-sought freedoms. ${ }^{3}$ This Comment argues that some two hundred years after the passage of the Bill of Rights, new-age informational tactics exploit the text of the First Amendment contrary to its intent. Thus, the situation amounts to nothing less than tyranny against which the Amendment was intended to protect.

In today's age of user-generated content ${ }^{4}$ and widely-perceived media bias, ${ }^{5}$ private, federal, and commercial forces clash over access to the minds of citizenry on the informational battlefield. As a result, the integrity of such concepts as media credibility, impartiality, and independence are at great risk. Legislative oversight of the media, commonly perceived as violative of the First Amendment, is for the most part non-existent, ${ }^{6}$ and, as such, leaves the integrity of the media hinging on self-imposed "journalistic codes of ethics."7 Moreover, the technological reality of the Internet has enabled an exchange of ideas unprecedented in scope. ${ }^{8}$ Today, any individual or organization may successfully compete with traditional mass media for almost immediate access to the minds of millions: an extraordinary power which has not been immune from malicious exploit. ${ }^{9}$

2. See John R. Vile, The Constitutional CONVENTION OF 1787630 (2005).

3. The First Amendment secured, inter alia, freedom of speech, freedom of religion, and freedom of the press. See U.S. CoNST. amend. I.

4. "User-generated content refers to information and material that is created by Internet users themselves. The term came into the mainstream in 2005 as a result of the irresistible boom of the 'do-it-yourself Web.' It describes all types of data produced and posted by users, such as messages, photos, movies or audio files." TIMO BECK, WEB 2.0: USER-GENERATED CONTENT IN ONLINE COMMUNITIES 19 (2008).

5. See e.g., Jim Rutenberg, A Surge on One Channel, a Tight Race on Another, N.Y. Times, Nov. 2, 2008, at A28. See also discussion infra Part III.A.1.

6. See discussion infra Part IV.

7. The author argues that "journalistic codes of ethics" alone are not effective in ensuring impartiality and independence of the media. But cf. Blake Morant, The Endemic Reality of Media Ethics and Self-restraint, 19 NOTRE DAME J. OF LAw, ETHICS \& PUB. POL. 595, 599 (2005) ("Despite their ostensible lack of authority and susceptibility to the omnipresent pressure for ratings and profit, mechanisms such as ethical codes and other forms of self-restraint remain effective industry-wide norms and cognitive guide-posts that promote responsible journalism. Exercised conscientiously and explicitly, self restraint remains the most viable and efficient means to ensure the media's functionality within a modern democratic society.").

8. See Jo AnN Oravec, Virtual Individuals, Virtual Groups 4 (1996) ("Both the printing press and the computer are linked historically with substantial changes in the way individuals view themselves. ... [T] he advent of the computer will have at least as large and as dramatic impact on civilization as that of the printing press. ...").

9. See discussion infra Part III. 
The regular misuse of informational leverage by partisan groups, whether in private, governmental, or commercial settings, has long been exposed and condemned. ${ }^{10}$ Ironically, however, an effectual response is most likely shielded by the text of the First Amendment. This inherent side effect of the First Amendment is reflected in the words of Noam Chomsky:

In a totalitarian state, it doesn't matter what people think, since [one] can control people by force using a bludgeon. But when you can't control people by force, you have to control what people think, and the standard way to do this is via propaganda (manufacture of consent, creation of necessary illusions), marginalizing the general public or reducing them to apathy of some fashion. ${ }^{11}$

Accordingly, Part II of this Comment argues that while the First Amendment secured fundamental liberties, it also unavoidably outlawed control over the flow of information, ${ }^{12}$ and it did so without eliminating the fundamental human vice of self-interest. ${ }^{13}$ As a consequence, the informational battlefield is devoid of any rules of engagement.

Part III of this Comment examines several historical examples of misuse of the First Amendment freedoms carried out in pursuit of private and governmental self-interest; this examination includes several telling examples from the 2008 presidential election. Part III also reviews traditional tactics employed in informational warfare and considers newage developments brought about by the millions of Internet participants.

Furthermore, Part III of this Comment argues that the First Amendment and technology in their present coexistence have

10. See id.

11. Manufacturing Consent: Noam Chomsky and THE Media (Humanist Broadcasting Foundation 1992) [hereinafter CHOMSKY DOCUMENTARY FILM].

12. See U.S. CONST. amend. I.

13. The author takes the position that self-interest is primarily a vice rather than a virtue, and that a society built on the primacy of individual material gain exists in an irreconcilable moral contradiction. Adam Smith declared:

It is not from the benevolence of the butcher, the brewer, or the baker that we expect our dinner, but from their regard to their own interest. We address ourselves, not to their humanity but to their self-love, and never talk to them of our own necessities but of their advantages.

Adam SMith, AN InQuiry InTo The Nature And Causes Of The Wealth Of Nations By AdAM Smith 19 (C.J. Bullock ed., P.F. Collier \& Son Company 1909) (1776) (emphasis added).

The view that self-interest is a benefactor of society at large is now widely held. See, e.g., CHOMSKY DOCUMENTARY Film, supra note 11 ("Modern industrial civilization has developed within a certain system of convenient myths the driving force of modern industrial civilization has been individual material gain, which has been accepted as legitimate, even praiseworthy, on the grounds that private vices yield public benefit in the classic formulation."). 
inadvertently enabled the vice of self-interest to adulterate the ideals of liberalism. To wit, technological ability has elevated the effectiveness of, inter alia, stealth indoctrination, marginalization, and flag waving to a new level, while the First Amendment is exploited to justify the underlying actions by classifying them as "protected activities" within the scope of the Constitution.

Part IV of this Comment then examines the present regulatory regime which has been largely impotent in curbing the widespread abuse. Part IV is also critical of congressional ineptitude in dealing with numerous examples of such abuse, but, nevertheless, the author looks to Congress for a fix. After all, the legislature's record is not entirely devoid of success.

Part $\mathrm{V}$ of this Comment proposes legislative action, which, as a start, could include the Federal Propaganda Prohibition Act of 2005. More broadly, the legislation should help restore the integrity of such concepts as media independence and devise an accuracy-labeling scheme in reporting. ${ }^{14}$ Additionally, the legislation should elevate the responsibility of accredited media beyond a "journalistic code of ethics" and codify a journalistic standard of care. However, any such action must not infringe on the intent of the First Amendment or roll back the gains of progress. In the absence of congressional action, the country will continue to slide down the slope of informational misuse to a new type of informational tyranny. ${ }^{15}$

\section{HISTORICAL BACKGROUND AND THE FIRST AMENDMENT}

-The pen is mightier than the sword. ${ }^{16}$

\section{A. Technology: The Catalyst of Change}

Johannes Gutenberg, ${ }^{17}$ the inventor of the printing press, and Joseph Goebbels, ${ }^{18}$ the Third Reich's propaganda minister, would have

14. See infra Part V.

15. Here and throughout this Comment, the author is not critical of anything merely for criticism's sake. My intent in identifying problems reflects my search for a solution so that, ultimately we may continue, as a society, our quest for "a more perfect union." U.S. CONST. pmbl.

16. EdWARD Bulwer-LytTon, RichelieU; OR the CONSPIRACy 8 (John $\mathrm{M}$. Kingdom ed., R. M. De Witt, 1874) (1839).

17. German goldsmith and printer who is commonly accepted as the first European to use moveable type. Gutenberg is also commonly credited with the invention of the mechanical printing press. See generally ALBERT KAPR ET AL., JOHANNES GUTENBERG: THE MAN AND HIS INVENTION (Douglas Martin, trans., 1996) (comprehensive overview of the life of Johannes Gutenberg). 
something to talk about. After all, much of Goebbels's work was memorialized by mechanical moveable type. ${ }^{19}$ In a way, Goebbels would agree with American abolitionist Wendell Phillips ${ }^{20}$ that "[w]hat gunpowder did for war the printing press has done for the mind."21 Although Gutenberg's forty-two-line Bible left a legacy different from Goebbels's columns in Das Reich, ${ }^{22}$ both Goebbels and Gutenberg recognized the remarkable power of accessible print to influence the minds. Nevertheless, at times this realization left the two men working for the same prize from opposing directions: burning two dozen books may, in fact, be a more euphoric undertaking (or at least a quicker one) than reading the Old Testament in a forty-two-line print. However, Goebbels's did not limit his propagandist efforts to book burning crusades alone. $^{23}$ In 1945, when he had the difficult task of convincing a war-torn German nation that it was suffering for a rightful cause, ${ }^{24}$ he penned these words:

Rarely in history has a brave people struggling for its life faced such terrible tests as the German people have in this war. The misery that results for us all, the never ending chain of sorrows, fears, and spiritual torture does not need to be described in detail.... We are bearing a heavy fate because we are fighting for a good cause, and are called to bravely endure the battle to achieve greatness. ${ }^{25}$

18. Minister of Public Enlightenment and Propaganda of Nazi Germany and close associate of Adolf Hitler. After Hitler's suicide, Goebbels became 25th Chancellor of Germany and 2nd Chancellor of the Third Reich. See generally DAVID IRVING, Goebbels: Mastermind of The Third Reich (Focal Point Publications, 2d ed. 1997) (1996) (biography of Joseph Goebbels).

19. Mechanical moveable type was gradually phased out with the invention of offset printing, which became the prevalent form of printing by mid 20th century. See generally STEPHAN FUSSEL, GUTTENBERG AND THE IMPACT OF PRINTING (Douglas Martin, trans., 2005) (describing the history of the printing art).

20. 19th century American abolitionist.

21. JAMES WOOD, DiCTIONARY OF QUOTATIONS FROM ANCIENT AND MODERN ENGLISH AND FOREIGN SOURCES 535 (F. Warne and Co., 1899) (quoting Wendell Phillips).

22. A propaganda newspaper founded by Goebbels that often contained Goebbel's own work. See IRVING, supra note 18.

23. Goebbels was the mastermind behind many of the book-burning crusades in the 1930s and 1940s. See id. See generally Gerhard L. WeinBerg, A World at Arms (1995) (global history of World War II).

24. In 1945, Germany was engaged in the deadliest conflict in human history, World War II, in which it lost over 7 million people. See WEINBERG, supra note 23 (global history of World War II).

25. Joseph Goebbels, Fighter for the Eternal Reich, DAS REICH, Apr. 8, 1945, available at http://www.calvin.edu/academic/cas/gpa/goeb74.htm. 
Today, reading over this excerpt, one may justly cringe under the feelings of sacrilege: history has long placed Dr. Goebbels and the Nazi regime in their deserved place. ${ }^{26}$

Consider, perhaps, a more open-ended example: Philo Farnsworth and Vladimir Zworykin are generally credited with the invention of television. ${ }^{27}$ Numerous accounts indicate that neither inventor was thrilled with the programming that quickly filled the vacuum in cathode ray tubes ${ }^{28}$ or the informational "vacuum" in the American households. ${ }^{29}$ Despite the cool reception from its inventors, television rapidly became an unprecedented medium for advancing ideas. ${ }^{30}$ In the highlypoliticized 1960s, forty-one years after the original introduction of the first working television system, some 600 million viewers tuned in to

26. See WEINBERG, supra note 24.

27. An ongoing controversy exists as to the "true inventor" of television. The author does not make any conclusive judgments on the matter but includes the following facts for curious readers. Zworykin filed patent \#2,141,059 for "television system" in 1923. U.S. Patent No. 2,141,059 (filed Dec. 29, 1923). Farnsworth filed patent \# 1,773,980 for "television system" in 1927. U.S. Patent No. 1,773,980 (filed Jan. 7, 1927). Famsworth won patent interference action. Farnsworth v. Zworykin, No. 64027 (U.S. Patent Office Apr. 24, 1934). But see Married, TIME, Nov. 26, 1951 ("Vladimir Zworykin, 62, Russian-born, Russian-trained physicist, the 'father of television,' who developed the iconoscope (eye) of the TV camera in 1923, now laments: 'We never dreamed of Howdy Doody on Television - we always thought television would find its highest value in science and industry."') (emphasis added).

Although Farnsworth prevailed in the 1934 decision, he went on to lose several other patent battles with RCA, Zworykin's principal employer. See generally ALBERT ABRAMSON, THE History OF TELEVISION, 1880 to 1941 (1987) (recounting these events in greater detail). Additionally, Zworykin is commonly credited with the design of the iconoscope, a principal component in the first commercially available television sets. See generally id.; Married, Time, Nov. 26, 1951.

28. Cathode-ray tubes are vacuum tubes, a central component in most of the last century's television systems. See generally Geoffrey PARR, THE CATHOdE RAy TUBE AND ITS APPLICATION 1941 (general overview of the early uses of the cathode ray tubes).

29. See Neil Postman, Electrical Engineer, TIME, March 29, 1999, at 92 (quoting Farnsworth's son Kent as saying of his father: "I suppose you could say that he felt he had created kind of a monster, a way for people to waste a lot of their lives. Throughout my childhood his reaction to television was, 'There's nothing on it worthwhile, and we're not going to watch it in this household, and I don't want it in your intellectual diet."'); TIME, supra note 27 (Zworykin's reference to "Howdy Doody"); Interview with Elma ("Pem") Farnsworth, widow of Philo T. Farnsworth, in Fort Wayne, Ind. (Apr. 12, 1999), available at http://www.youtube.com/watch? $\mathrm{v}=9$ _vbkg2eg64 (Interviewer: "But [Philo] knew what was on [television]? Pem: "That's why we didn't even have a set."); Marry Bellis, Vladimir Zworykin 1889-1982, http://inventors.about.com/od/xzstartinventors/ a/Zworykin.htm (quoting Zworykin on his feelings about television: "I hate what they've done to my child. .. . I would never let my own children watch it."); see generally EVAN I. SChwartz, The Last Lone Inventor: A Tale Of Genius, Deceit, AND The Birth OF Television (2002); Daniel Stashower, The Boy Genius and The Mogul: The UNTOLD STORY OF TELEVISION (2002) (recounting the history of early television).

30. See John M. Sarkissian, On Eagle's Wings: The Parkes Observatory's Support of the Apollo 11 Mission, Publications OF THE Astronomical SOC'Y OF AUSTL., 287 (volume 18, 2001). 
watch the black and white transmission of the Apollo 11 moon landing. ${ }^{31}$ Among them were Philo Farnsworth and his wife Elma. Elma later recounted this moment:

Interviewer: The image dissector was used to send shots back from the moon to earth.

Elma Farnsworth: Right.

Interviewer: What did Phil think of that?

Elma Farnsworth: We were watching it, and, when Neil Armstrong landed on the moon, Phil turned to me and said, "Pem, this has made it all worthwhile." Before then, he wasn't too sure.

The emotional charge behind this recollection is indicative of the power of communicated ideas to influence people. Until that moment in 1969 , no government or person was ever able to reach and move 600 million people at once. ${ }^{33}$ The societal transformation that resulted from this giant technological leap from Gutenberg's Bible to live television may well be summed up by John Lennon's "[w]e're more popular than Jesus now." 34 The technology realigned people's most basic values and interests.

\section{B. From a Bludgeon to the First Amendment}

Throughout history, technological innovation has ushered in societal change. ${ }^{35}$ As progress made its way from the knots of the Incan quipu rope $^{36}$ to blogging at the speed of thought, so largely parallel and impressive was the rise of liberalism, for which technology served as an enabling catalyst. ${ }^{37}$ The printing press was the "catalyst for Protestant

31. See id.

32. Interview with Elma ("Pem") Farnsworth, widow of Philo T. Farnsworth, by Jeff Kisseloff in Salt Lake City, Ut (Jun. 25, 1996), available at http://www.youtube.com/ watch?v=LDUU4bgyt8o.

33. See Sarkissian, supra note 30.

34. Interview by Maureen Cleave with John Lennon (1966), available at http://beatlesnumber9.com/biggerjesus.html.

35. See generally RafaEl Aguayo, The Metaknowledge Advantage (2004) (arguing broadly that technological innovation brings about societal and economic change).

36. A record-keeping device of the Inca empire consisting of a series of variously colored strings attached to a base rope and knotted so as to encode information. See

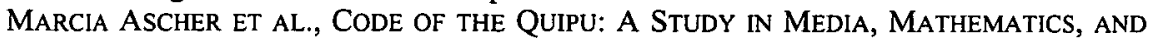
CULTURE 14 (1981).

37. See Elizabeth L. Eisenstein, The Printing Press as an Agent of Change 454 (1980); ORAVEC, supra note 8, at 4 ("Both the printing press and the computer are linked 
Reformation, the Renaissance, and the Industrial Revolution. ${ }^{38}$ A wave of political revolutions had followed. The English Revolution of 1688 and the subsequent passage of the English Bill of Rights of 1689 shook the pillars of absolutism and marked the rise of liberal thought. ${ }^{39}$ The English revolutionary events of 1688 included the foreshadowing of the free press. ${ }^{40}$ John Milton's political anticipations concerning the "emancipation" of the English press and literature were partially realized: "[a] noble and puissant nation roused herself like a strong man after sleep, and shook her invincible locks."

Subsequently, during the 17 th, 18 th, and 19 th centuries, the printing technology and the attendant spread of ideas enabled liberalism to effect societal change throughout a host of countries. Then-present governmental and societal structures in Denmark-Norway, Sweden, Russia, France, as well as in the American Colonies, among others, all "fell victim" to the spread of liberal ideals. ${ }^{42}$ The broad societal emancipation was neither quick nor painless, and the change was often earned in bloodshed. ${ }^{43}$ Moreover, ugly relapses frequently delayed the celebration. ${ }^{44}$ John Milton would have been disappointed to learn that the "noble and puissant" empire would again immerse itself in coups and intrigue, deny and suppress liberal movements within its borders, and eventually lose control over most of its colonies. ${ }^{45}$ Similarly in France, Napoleon Bonaparte traded the liberal gains of the French Revolution for

historically with substantial changes in the way individuals view themselves.... [T] he advent of the computer will have at least as large and as dramatic impact on civilization as that of the printing press. ...").

38. See Aguayo, supra note 35, at 179.

39. "Liberal thought," meaning the reflections of the ideals of classical liberalism, i.e., personal, intellectual, and economic liberties. See generally PIERRE MANENT ET. AL., AN INTELlECTUAL HISTORY OF LIBERALISM (Rebecca Balinski, trans., 1996) (a comprehensive overview of traditional liberalism that includes a review of Locke, Hobbes, Rousseau, Guizot, and Constant). For a description of the English revolutionary events of 1688, see Charles DukE Yonge, History of THE ENGlish Revolution of $1688(1874)$.

40. See YONGE, supra note 39, at 268 (documenting the "emancipation" of English literature and press during the events of 1688).

41. Id. (quoting John Milton).

42. See generally HeInZ Lubasz, Revolutions in Modern European History (1966); W. Chambers, France, Its History and Revolutions (1873); Byron J. Nordstrom, THE History of SWEden (2002); R. Nisbet Bain, Scandinavia, A POlitical History of DenMark, NORWAY AND SWEDEN From 1513 To 1900 (1905); MerRill Jensen, The Founding of a Nation: A History of AMERICAN REVOlution, 1763-1766 (1968) (each book recounting the revolutionary events in those countries).

43. See generally LUBASZ, supra note 42 (revolutions, by definition, are violent overthrows).

44. See id.

45. See generally KINGSLEy BRyCE SMellie, Great Britain SinCe 1688 (1962) (an in-depth history of Great Britain after the revolutionary events of 1688). 
autocratic military rule: The Napoleonic Wars infamously ended the lives of millions. ${ }^{46}$

These historical events, as they unfolded in many countries in the centuries following the invention of the printing press, are strikingly similar in their end result: the people would, generally, establish as axiomatic their "unalienable rights," consistently attained at the ruins of political regimes.

For example, when ratified, the United States Constitution, and more specifically the First Amendment, memorialized the pinnacle of liberal thought. ${ }^{48}$ However, the First Amendment came at the expense of the national interest of the British Empire, which simply lost thirteen of its colonies in North America ${ }^{49}$ (from a British perspective this event amounted to a much more pragmatic occurrence than the "triumph of liberal thought"). Analogously, the populace of Imperial Russia, and later the Soviet Union, was similarly influenced by the spread of "progressive" ideas when it first overthrew the hereditary rule in a bloody civil war $^{50}$ and later peacefully renounced its status as a superpower in a trade-off for democratic utopia. ${ }^{51}$ The French, however, may have topped everyone: in their volatile socio-political quest they have disposed of several dynasties, monarchies, and a handful of republics. ${ }^{52}$

In short, these examples illustrate a very strong governmental interest in maintaining the status quo, whether under a people-issued mandate or otherwise. ${ }^{53}$ Unfortunately, as history repeatedly indicates,

46. See Alan Warwick Palmer, et al., An ENCYClopedia of Napoleon's Europe vii (1984) (Napoleon "was [a] military conqueror and legislator, dynastic iconoclast"); see also SAMUEL DUMAS, ET AL., LOSSES OF LIFE CAUSED BY WAR (1923).

47. See, e.g., THE DECLARATION OF INDEPENDENCE para. 2 (U.S. 1776).

48. "Liberalism! Not in all history has a word been so wrenched away from its true meaning and dragged through the gutter of defilement," declared George Creel in a 1947 memoir. "Where it once stood for the dignity of man,... it now stands for the obliteration of individualism at the hands of a ruthless, all-powerful state." GEORGE CREel, Rebel at LaRge (1947), quoted in Otis Graham, An EnCORE for Reform: ThE Old PROGRESSIVES AND THE NEW DEAL 90 (1967).

49. See generally Merrill Jensen, The Founding of a NATion: A History of the AMERICAN REVOLUTION, 1763-1766 (1968) (describing the American Revolution and the subsequent independence of the colonies).

50. See generally EVAN MAWDSLeY, THE Russian Civil WaR (2007) (A thorough history of the Russian Civil War, a struggle for a utopian dream that promised workers power, peace, and land reform, and that resulted in the loss of seven million lives.).

51. See generally JOHN B. DUNLOP, THE RISE OF RusSIA AND THE FALl OF THE SOVIET EMPIRE (1995) (describing events that amounted to one of the great bloodless revolutions of the twentieth century).

52. See generally Roger Price, A Concise History of France (2005) (an up-todate guide to French history).

53. The author does not suggest that any state interest in maintaining the status quo is illegitimate. Many circumstances warrant legitimate perpetuation of state interests. 
the ruling political elites are rarely picky in their methodology; anything goes in order to preserve the dominion. Historically, that meant a bludgeon. Today, however, it is "the manufacture of consent." 54

\section{From the First Amendment to the Manufacture of Consent}

When the rapid propagation of ideas effected societal change, the states' core interests, including self-preservation, suddenly became threatened. In response, the states added a weapon ${ }^{55}$ to their arsenals, and the concept of ideological warfare was born. ${ }^{56}$ Although few would disagree that the ideological underpinnings of the Nazi Germany and the 1960s America were at large dissimilar, the use of the available mass media to perpetuate state interests was a strategic reality for both of these regimes. ${ }^{57}$ Moreover, the use of mass media has become a fundamental part of upholding past and present political structures the world over. ${ }^{58}$

Walter Lippmann, a prominent American writer and journalist, unveiled almost a century ago the central issue addressed in this Comment:

The creation of consent is not a new art. It is a very old one which was supposed to have died out with the appearance of democracy. But it has not died out. It has, in fact, improved enormously in technic, because it is now based on analysis.... [A]s a result of psychological research, coupled with the modern means of

However, if democratic values are to be upheld, any such action must be under a peopleissued mandate.

54. WALTER LiPPMANN, PUBLIC OPINION 248 (1922).

55. See supra notes $18,22,35$ and accompanying text.

56. "Ideological warfare" arguably existed for as long as humankind. Here, the term "ideological warfare" is used as a tactic that employs modern-day technology to influence masses of people. See generally Garth JowetT ET Al., Propaganda And Persuasion (2006) (a comprehensive history of propaganda and insightful definitions and methods to analyze it).

57. There is, of course, abundant evidence of the use of mass media for propaganda in Nazi Germany. For example, one of Goebbels's official positions was "Minister of Public Enlightenment and Propaganda of Nazi Germany." As such, he was actively engaged, living up to his title. See IRVING, supra note 18; see also supra note 10 and accompanying text.

The discussion on the use of propaganda in the United States is an integral part of this Comment. See infra Part III. The author contends that the previously-mentioned Apollo 11 mission, and the space race in general, likely had at their core political rather than scientific objectives (e.g., waving of the flag, a propaganda technique, on the moon surface). See, e.g., Deborah Cadbury, Space Race: The Epic Battle Between America AND The Soviet Union For Dominion Of SPACE (2006). The author, at the same time, does not suggest that installation of the flag on the moon surface was inappropriate. This example merely illustrates that governments may effectively rally people to achieve a particular purpose.

58. See JowETT, supra note 56. 
communication, the practice of democracy has turned a corner. A revolution is taking place infinitely more significant than any shifting of economic power.

Walter Lippmann, in 1922, long before the 1969 Apollo 11 broadcast, recognized the change that was being wrought by "thenmodern" means of communication. ${ }^{60}$ A theoretical gap then suddenly emerged between the classical definition of democracy, where the supreme power is held by the people, and the American political reality of the 1920s. ${ }^{61}$ In fact, Lippmann was so disillusioned with the possibility of the existence of classical democracy that he advocated for a governing class of bureaucrats who would be armed with knowledge and information, and who would face, on behalf of the people, the future challenges. $^{62}$ According to Lippmann, a "wise leader,"63 in order to succeed, had to "seek a certain measure of consent" through the "manufacture of consent." 65

The manufacture of consent, or broadly, propaganda, is designed to serve the specific interests of the propagandist. Although the author contends that Walter Lippmann's political aspirations were fundamentally realized and that the country, at large, has been run by a specialized class which has access to classified information that the general populace would meet, as Lippmann argued, with an "anguished yawn," 66 the reader may disagree. The author, however, argues categorically that the manufacture of consent became an everyday reality in the American political, social, and commercial realms. ${ }^{67}$ The following section examines several historical examples of propaganda. The review of some of the recent cases is benefited by hindsight, which was not available to Walter Lippmann. Perhaps history will add a measure of clarity to this analysis.

59. Walter Lippmann, Public Opinion 248 (1922) (emphasis added).

60. See id.

61. See id.

62. See id. at 285.

63. See id. at 245 .

64. Id.

65. Id. at 248.

66. Id. at 398 .

67. Of course, the United States is not the only country in which certain political, social, or commercial forces utilize mass media for the manufacture of consent. The author, however, argues that the liberal gains of the First Amendment have been circumscribed by habitual abuse, and the situation is an unfortunate, but accurate, reflection of the present-day America. See infra Part III. 


\section{Conclusion:}

Throughout time, technology enabled positive, liberating societal change. The control over the minds of people thus evolved from a bludgeon to the manufacture of consent.

\section{HISTORICAL AND MODERN-DAY USE OF PROPAGANDA IN THE UNITED STATES}

\section{A. The Central Role of the Media in the Delivery of Propaganda}

Not every variance of opinion and its accompanying expression is propaganda. Propaganda is generally aimed at influencing a broad audience, and those who employ it are more concerned with the end result than with the accuracy of disseminated information. ${ }^{68}$ Unlike an earnest debate, where variance of opinion seeks to illicit an ultimate truth, propaganda aims to instill a belief or provoke a reaction in the recipients regardless of accuracy in the delivered message. ${ }^{69}$ However, not all propaganda carries with it an ignoble stigma of falsehood. If we accept a particular value as an absolute good, then as a society, we also accept the propagation of this value. For example, literacy is generally accepted as an absolute good, and therefore, parents consent to and encourage the teaching of reading to their children. Our society chooses to advertise literacy through campaigns and initiatives. ${ }^{70}$ Once children learn how to read, the parents may then limit children's access to some information and encourage their access to others. Responsible information filtering by parents is an example of an acceptable social practice. $^{71}$

On the other hand, the manufacture of consent, whether pursued by a specialized (governmental) class as in Lippmann's version of democracy $^{72}$ or by some other interested group may or may not be in the broad societal interest. As established in Part II, the liberal gains outlawed control over people with a bludgeon, ${ }^{73}$ and the technology enabled the propagandists to reach the populace en masse. ${ }^{74}$ Alongside technology, the methods of propaganda also evolved. Whereas historical

68. See JowETT, supra note 56, at 1 and accompanying text.

69. See id.

70. See, e.g., The Literacy Campaign for Monterey County, http:/www.literacy campaignmc.org; Multicultural Literacy Campaign, http:/www.literacycampaignmc.org.

71. However, information filtering often becomes a questionable practice when carried out by the government or by the commercial media. In fact, in that context it would qualify as a propaganda technique. See infra Part III.B.4.

72. See discussion supra Part II.C.

73. See supra note 11 and accompanying text.

74. See supra Part II. 
dissemination of information depended, at large, on print medium, today's propaganda employs a much wider spectrum of delivery. ${ }^{75}$ Several historical examples provide a valuable insight into the evolution of propaganda in America.

\section{B. Historical Examples of Propaganda in the United States}

\section{Pre-ratification}

Interestingly, the Federalist Papers ${ }^{76}$, propaganda at their core $^{77}$, partially paved the way for the original Constitution and the First Amendment. Passage of the Bill of Rights would have been impossible without the preceding ratification of the Constitution itself. ${ }^{78}$ In this sense, the Federalist Papers, which advocated ratification, also ushered in the passage of the Bill of Rights. ${ }^{79}$ The Anti-Federalists, who were among the leaders of the American independence movement, but who did not support the ratification of the original Constitution, wrote similar essays, the Anti-Federalist Papers. The Federalist and Anti-Federalist essays were persuasive documents written with all the eloquence the authors could muster. ${ }^{80}$ To the victors go the spoils: the Federalists prevailed, and the Constitution was passed. ${ }^{81}$ The authors of the prevailing opinions went on to become prominent public figures in the nation they helped create. Alexander Hamilton became the first Secretary of the Treasury, John Jay became the first Chief Justice, and James Madison became the Fourth President. In contrast, the AntiFederalists were largely excluded from the high political posts of the

75. See JowETT, supra note 56, at 93 (also noting how each delivery method contributed to the creation of new propaganda techniques).

76. See generally AlEXANDER HAMILTON ET AL., THE FEDERALIST (John C. Hamilton ed., J.P. Lippincott \& Co. 1869) (1788) (The Federalist Papers are a collection of essays that, at large, advocated the ratification of the United States Constitution.).

77. The Federalist Papers were propaganda in a sense that they clearly advocated a purpose, and their end result was directed at moving others to action. The delivery medium, print, was the most effective medium of the time. See id; see generally FUSSEL, supra note 19 (printing was top method of exchanging ideas).

78. Meaning that the Bill of Rights were amendments to the Constitution, and if the Constitution did not pass (that is, if the Federalist Papers were less persuasive), then the Bill of Rights would not have had a Constitution to amend.

79. Many credibly argue that the Bill of Rights is the achievement of the AntiFederalists rather than the Federalists. See generally SAUL CoRnEll, THE OTHER FOUNDERS: ANTI-FEDERALISM AND THE DISSENTING TRADITION IN AMERICA, 1788-1828, (1999) (history of anti-federalism).

80. See HAMILTON, supra note 76 and accompanying text.

81. See U.S. CONST. 
early Federation. ${ }^{82}$ Although the Federalists' personal interests may have been merely aligned with the higher interests that are commonly attributed to the Founding Fathers, ${ }^{83}$ the Federalist Papers represent an effective use of available media to influence opinions so as to achieve a particular purpose.

\section{Alien and Sedition Acts}

The volatile times that followed the passage of the Bill of Rights presented an immediate test to the recently passed First Amendment. ${ }^{84}$ The four laws known as the Alien and Sedition Acts of 1798 outlawed, inter alia, publication of "false, scandalous, and malicious writing" against the government or its officials. ${ }^{85}$ The Acts were an attempt to limit any disruptive influence by France or its agents following the outbreak of the Quasi-War. ${ }^{86}$ The abridging of the freedom of speech and of the press by the Sedition Act demonstrated the non-absolute nature of these freedoms. In fact, consider the opinion of Anthony Lewis: " ${ }^{87}$ "But in truth the freedoms of speech and of the press have never been absolutes. The courts and society have repeatedly struggled to accommodate other interests along with those." 88 The Alien and Sedition Acts are an example of a superseding state interest of self-preservation: the proponents of the Act argued that the limitation of First Amendment

82. E.g., Patrick Henry, the author of the "Give me Liberty or give me Death!" speech, one of the most prominent revolutionaries and two-time governor of Virginia was, at large, excluded from any federal posts (although George Washington offered him the position of the Secretary of State, which Henry declined. See MoSES COIT TYLER, PATRICK HENRY 358 (1887)).

The authors of Federalist and Anti-Federalist Papers used pseudonyms. Whereas the historic authors of the Federalist Papers have been identified with great certainty, a reasonable dispute still exists about the authors of the Anti-Federalist Papers. If George Clinton and Cato are appropriately linked, then the author is required to note that George Clinton served as Vice President of the United States under both Thomas Jefferson and James Madison. For further reading on the subject see generally MERRILL JENSEN ET AL., THE DOCUMENTARY HISTORY OF THE RATIFICATION OF THE CONSTITUTION (1976) (a thorough history of ratification events).

83. See, e.g., GORDON S. WOOD, Revolutionary Characters: What MADE THE FOUNDERS DIFFERENT (2006) (generally upholding the trend of idealizing the founders).

84. The United States were at this time engaged in what later became known as the Quasi-War with France, a de-facto naval war. See generally ALEXANDER DECONDE, THE QuASI-WAR: The Politics AND Diplomacy of THE UNDEClaRed WaR WITH FrancE 1797-1801 (1966) (a history of the Quasi-War).

85. See Richard D. HeFfner, A DOCUMENTARY History OF THE UNITED States 73 (2002).

86. See generally DECONDE, supra note 84.

87. Anthony Lewis, an American author and intellectual, winner of several Pulitzer Prizes.

88. ANTHONY LeWIS, FREEdOM FOR THE ThOUGHT That WE HATE 169 (2007). 
freedoms was justified in light of wartime conditions. ${ }^{89}$ One way or another, circulation of certain information was made criminal because of a perceived threat to a young regime; a governmental and arguably a societal interest circumscribed the freedom of speech. ${ }^{90}$

\section{Endorsement of Political Candidates by the Media, an Example of Political and Social Antique}

Throughout time, the country's political life would hardly exist without the press. ${ }^{91}$ And in the early days, if a newspaper were to survive, it had to rely on a sponsorship of a political party. ${ }^{92}$ Press and politics have long existed in this symbiotic relationship. ${ }^{93}$ Historically, political bias in newsprint was widespread and acceptable; "partisan control dominated the media landscape."94 As part of a common practice, the newspaper editorial boards endorsed political candidates who belonged to the newspaper's sponsoring party. ${ }^{95}$

For example, The New York Times ${ }^{96}$ was founded in 1851 by Henry Jarvis Raymond, ${ }^{97}$ an American politician affiliated with the Republican

89. See Craig R. Smith, Silencing the Opposition 8-9 (1996).

90. Although the Alien and Sedition Acts may in some respects have limited the freedom of speech, these Acts, nevertheless, serve as excellent examples of the nonabsolute nature of the rights of free speech and free press. The Acts were passed in response to a real threat which, arguably, could have weakened or brought down a young Nation. See id. Similarly today, legislation that accounts for modern technological realities and introduces certain checks on media behavior may be in the best interest of the country. For further discussion, see infra Parts IV and V.

91. See Hazel Dicken-GarCia, Journalistic Standards In Nineteenth-Century AMERICA 30 (1989); see also Jodie Morse, Note, Managing the News: The History and Constitutionality of the Government Spin Machine, 81 N.Y.U.L. REV. 843, 847-50 (2006) (discussion of historical and present governmental efforts to manage the news).

92. See DICKEN-GARCIA, supra note 91, at 30-31, 39-40 (according to some estimates more than 4000 periodicals were still funded by a political party at the end of the Civil War).

93. See generally id. (documenting such a relationship).

94. Morse, supra note 91 , at 847.

95. See DiCKEN-GARCIA, supra note 91 , at 39 .

96. The New York Times is, perhaps, the most influential newspaper in the United States. It is the largest metropolitan newspaper; it has won ninety six Pulitzer Prizes, more than any other newspaper. See The New York Times Company, About the Company, http://www.nytco.com/company/awards/index.html (last visited Jan. 07, 2009). On January 7 th, 2009 , its website was the 25 th most visited website in the United States and the 91 st most visited website worldwide. See Alexa, The Web Information Company, http://www.alexa.com/data/details/main/nytimes.com (last visited Jan. 07, 2009). In light of these facts, the author considers it appropriate to use The New York Times for several examples pertinent to the discussion. These examples follow in the text.

97. Henry Jarvis Raymond (1820-1869), an American journalist and politician, at one time a member of the House of Representatives, Chairman of the Republican National Committee, and the founder of The New York Times. 
Party. Starting with its inaugural presidential endorsement in 1860 and until 1884, The New York Times (or The Times) endorsed six Republican presidential candidates in a row. ${ }^{98}$ By the end of the nineteenth century, the concept of media impartiality became more relevant, and the newspapers began to declare political independence. ${ }^{99}$ Intriguingly however, the practice of endorsing political candidates survived past the shift towards media impartiality. In 1884, The Times endorsed Grover Cleveland, a Democrat. ${ }^{100}$ Not long after the proclaimed political independence, technology began to expand the reach of commercial media. $^{101}$ Theoretically, the credibility of now-independent media endorsements delivered to millions of subscribers also had to increase. The media truly began to emerge as what Thomas Carlyle appropriately dubbed the "fourth estate, more important far than they all."102

In the thirty-two most recent presidential elections, despite its claim to impartiality, The Times' editorial board endorsed a Democrat a stunning twenty-six times. ${ }^{103}$ Perhaps, even more interesting is its current streak of thirteen straight Democratic endorsements. ${ }^{104}$ The empirically measured influence of these endorsements is somewhat inconclusive: the endorsement matched the winner twenty-three times in thirty-eight elections. ${ }^{105}$ In the opinion of Karl Meyer, a former member of The Times editorial board, "sometimes what The Times does can make an enormous difference, and other times it has no influence whatsoever." most important effect of mass communication, its ability to mentally order and organize our world for us. In short, the mass media may not be successful in telling us what to think, but they are stunningly successful in telling us what to think about." ${ }^{, 107}$

The author opines that this tremendous influence must come with a degree of reasonable restraint. Of course, any such restraint cannot take

98. See Jon Huang et al., New York Times Endorsements Through the Ages, N.Y. TIMES, 2008, available at http://www.nytimes.com/interactive/2008/10/23/opinion/ 20081024-endorse.html.

99. See Michael Schudson, Discovering the News, a Social History of AMERICAN NEWSPAPERS 21 (1978).

100. See Jon Huang, supra note 98.

101. See supra Part II.

102. Meaning more important than the Clergy, Nobles, and Commons of the Parliament. Thomas Carlyle, et al., On Heroes, Hero-worship and the Heroic in HISTORY 228 (Houghton, Mifflin and Company 1907) (1841).

103. See Jon Huang, supra note 98.

104. See id.

105. See id.

106. CHOMSKY DOCUMENTARY FILM, supra note 11.

107. Donald Shaw et al., The Emergence of American Political issues: The Agenda SetTing Function OF the Press 5 (1977). 
away First Amendment liberties. Unlike the "fourth estate," the remaining "three estates" of the American government are subject to the checks laid down in the highest law of the land, the Constitution. The author advocates that political endorsements by the media exemplify a historic practice that has outgrown modern realities. Commingling objective news coverage with blatant endorsement of partisan politicians under the umbrella of a single publication destroys any claim of "freedom" in the press and leaves the "fourth estate" without any reasonable safeguard from abuse. ${ }^{108}$

\section{Stealth Propaganda}

Over time, as literacy rates and education levels have increased, the propaganda techniques have become more sophisticated so as to evade the guard of most people. ${ }^{109}$ As a result, some of the more effective methods of propaganda are the ones that remain undetected by the recipients. For example, information filtering is a stealth method of propaganda: the recipients rarely know about the important information they are not receiving. The following is an example of an effective use of this technique.

The Seventies saw some of the most horrible acts of genocide of the 20th century in East Timor and Cambodia. ${ }^{110}$ "Early seventies Cambodia [and] Timor are closely paired examples [of genocide].... [And] the media response was quite dramatic." 111 The New York Times coverage on Cambodia from 1975-1979 was 1,175 column inches. The similar atrocities in East Timor, for the same years, totaled a mere 70 column inches. ${ }^{12}$ The discrepancy in coverage is obvious. Consider the words of Karl Meyer, a former member of The New York Times editorial board, describing an appalling near non-existence of coverage on East Timor atrocities of the 1970s:

Chomsky ... made a very powerful case that the press underplayed the fact that the Indonesian government annexed this former Portuguese colony [East Timor] in 1975, and that, if you compared, for example, with Cambodia... this was a communist atrocity, whereas [East Timor] was not a communist atrocity.... Well, I got quite interested in this, and I went to talk to the then-deputy foreign editor of The Times, and I said: "You know, we've had very poor

108. For further discussion, see infra Part IV.

109. See generally JOWETT, supra note 56 (a comprehensive review of many propaganda techniques).

110. See CHOMSKY DOCUMENTARY FILM, supra note 11.

111. Id.

112. See id. 
coverage on this." And he said: "You're absolutely right. There are a dozen atrocities around the world that we don't cover; this is one [of them] for various reasons." 113

Among the "various reasons" that explain the lack of coverage on East Timor in the 1970s America, credence can likely be given to those connecting Timorese genocide to American foreign policy during the Cold War. ${ }^{114}$ Perhaps, Roosevelt's colloquialism concerning Anastasio Somoza Garcia ${ }^{15}$ also applies to the Indonesians: "[They] may be son[s] of bitche[s], but [they are] our son[s] of bitch[es]." "16 To the credit of Mr. Meyer and many other committed individuals, the events of East Timor eventually received far more appropriate coverage in the American press. ${ }^{117}$

Although The New York Times denied direction or pressure from "overlords in Washington"118 to suppress the coverage on East Timor, why was the coverage largely deficient? ${ }^{119}$ Perhaps patriotic journalists, intentionally or even subliminally, steered away from uncovering information that could damage their country's reputation. After all, they could easily write about similar atrocities carried out by a self-declared communist "son of a bitch," Pol Pot. ${ }^{120}$ Similarly then, could a reporter who intends to vote for a Republican presidential nominee be more inclined to cover a recent scandal in the Democratic Party rather than the mishaps of the Republican candidate? Can an entire news network appear to deliver information on a slant? Many argue so. ${ }^{121}$ Unfortunately, under the present, virtually non-existent regulatory scheme, nothing but the "restraints" of the "journalistic code of ethics" safeguard us from biased delivery of information. ${ }^{122}$

113. Id.

114. See supra note 113 and accompanying text.

115. Former president of Nicaragua who opposed the expansion of communism to Nicaragua. Many have labeled Garcia as a dictator. See ROBERT JACKSON ALEXANDER, PRESIDENTS OF CENTRAL AMERICA, MEXICO, CUBA, AND HISPANIOla 107 (1995).

116. Franklin D. Roosevelt quoted in PETER WINN, AMERICAS: THE ChANGING FACE OF LATIN AMERICA AND THE CARIBBEAN 544 (2006).

117. See CHOMSKY DOCUMENTARY FILM.

118. See id.

119. See id.

120. See David P. Chandler, Brother number One: A Political Biography of POL POT 7 (1999).

121. See discussion infra Part IV.

122. Id. 
5. Classification of Some Information by the Government and Propagation of Other Information, The Fake News

Democratic form of government, by its nature, calls for transparency. ${ }^{123}$ At the same time, the government has an affirmative duty to secure the interests of its voters. Classification of information generally serves the public interest by excluding national secrets from foreign enemies. ${ }^{124}$ Apparent conflict between transparency in government on the one hand and classification of information on the other has become the focal point of heated public debate time and again. Perhaps, the most known historic example of a classified information leak is the publication of the Pentagon Papers. ${ }^{125}$ Although, the issue remains highly controversial, many would agree that the disclosure elevated the accountability of the government. ${ }^{126}$ Initial attempts at publication met tremendous resistance, but eventually succeeded. ${ }^{127}$ The author believes that the publication of the Pentagon Papers under the protection of the Free Press Clause represented the golden age of the First Amendment protection. Arguably, in hindsight, the publication of the Papers was in the far better interest of the country than their concealment: the Papers told the truth about a conflict that had affected a great deal of citizenry on a personal level. ${ }^{128}$

In essence, classification of information is another example of information filtering carried out at a governmental level. ${ }^{129}$ Presently, the classification of information hinges on Executive Order 13292, issued by President George W. Bush. ${ }^{130}$ During the Bush administration, the classification of information has increased seventy-five percent. ${ }^{131}$ From 2001 to 2004, the annual volume of classification cases spiked from nine million to sixteen million. ${ }^{132}$

Political and governmental positions come with a heavy burden of public accountability, and, as a general matter, concealment of

123. See Michael Mandelbaum, Democracy's Good Name 155 (2007).

124. See, e.g., P. Stephen Gidiere, The Federal Information Manual 107 (2006).

125. "The Pentagon Papers" generally refers to a collection of originally classified history of American involvement in Vietnam. See generally DAVID RUDENSTINE, THE Day the Presses Stopped: A History OF the Pentagon Papers Case (1998) (detailed examination of jurisprudence dealing with the Pentagon Papers).

126. See, e.g., MANDELBAUM, supra note 123 , at 155 .

127. See RUDENSTINE, supra note 125 , at $48,125$.

128. See RUDENSTINE, supra note 125 , at 1 .

129. For more discussion on information filtering see supra Part III.A.

130. Executive Order 13,292.

131. Steven Aftergood, The Age of Missing Information: The Bush Administration's Campaign Against Openness, SLATE, Mar. 17, 2005, http://www.slate.com/id/2114963/.

132. See id. 
information by the government is inherently suspicious. ${ }^{133}$ This accountability can be minimized through concealment of information or by limiting transparency. Concealment of certain information then offers an easy escape from public scrutiny. On the other hand, positive news reports can vindicate or reinforce governmental actions.

Exactly this kind of news reports drew severe public fury around $2005 .^{134}$ From 2003 through the second quarter of 2005 , seven federal departments spent $\$ 1.6$ billion on 343 contracts with public relations firms, advertising agencies, media organizations, and individuals. ${ }^{135}$ What was previously described as "fake news" saw its best days during the Bush administration." In order to "catapult the propaganda," numerous "news" reports were put together by governmental employees who were acting as "reporters." production, these "news" reports were fed into the media reels and broadcast outlets throughout the country. ${ }^{140}$ Once this governmental interference became public, it drew sharp public and congressional reaction. $^{141}$ Among other legislative proposals, the Federal Propaganda Prohibition Act of 2005 was introduced in the House. ${ }^{142}$ Unfortunately, neither this bill nor any other effectual response emerged. ${ }^{143}$ Perhaps even more regrettably, the outcry against abuse in the media has subsided, and the framework of protection is yet to emerge. ${ }^{144}$

133. See generally Jimmy Wales et al., Commentary: Create a tech-friendly U.S. government, CNN, Jan. 8, 2009, http://www.cnn.com/2009/TECH/01/07/wales.obama. $\mathrm{cto} /$.index.html (arguing for "accountability born of transparency" in government).

134. See David Barstow et al., Under Bush, a New Age of Prepackaged News, N.Y. TIMES, Mar. 13, 2005, at A1; see also Christopher Lee, Update: Prepackaged News, Washington Post, February 14, 2006, at A13; Anne E. Kornblut et al., Debate Rekindles Over Government-Produced "News," N.Y. TIMES, Apr. 15, 2005, at A17; Gregory Klass, The Very Idea of a First Amendment Right Against Compelled Subsidization, 38 U.C. DAvis L. REv. 1087, 1129 (2005) (video news releases are "contrary to First Amendment principles").

135. See Christopher Lee, Update: Prepackaged News, WASHington POST, February 14,2006 , at A13.

136. David Lieberman, Fake News, TV Guide, Feb. 22, 1992, at 10, 11.

137. See generally Barstow, supra note 134, at Al (reporting in detail about the use of mass media by the Bush administration).

138. George W. Bush, quoted in Frank Rich, Two Top Guns Shoot Blanks, N.Y.TIMES, June 19, 2005, available at http://www.nytimes.com/2005/06/19/ opinion/19rich.html.

139. See Barstow, supra note 134, at A1.

140. Id. at A1, A34.

141. See Lee, supra note 134, at A13.

142. Federal Propaganda Prohibition Act of 2005, H.R. 373, 109th Cong. (2005).

143. See H.R. 373, 109th Cong. (2005). No major action has been taken on the bill since 2005 when the bill was referred to the House Committee on Government Reform. The present status of the bill is available at http://thomas.loc.gov/cgi-bin/bdquery/ z?d109:h.r.00373: (last visited Feb. 03, 2009).

144. See id. See also discussion infra Parts IV and V. 
6. Modern-day Developments, the Internet, and User-generated Content

"In modern-day warfare, some battles are conducted through the media.,"145

Today, progress has enabled the media to effectively employ several mediums of communication: television, radio, cinema, newspapers, magazines, and the Internet. It is difficult to imagine an average citizen who is not exposed to at least several of these mediums daily. The breadth of potential access to the minds of people through mass media presents a tremendous temptation to would-be propagandists. Recently, some of the traditional media sources such as newspapers ${ }^{146}$ have struggled financially, with many of them losing audience share to the Internet. $^{147}$

The significance of this shift can only be fully assessed while keeping in mind the make-up of Internet participants. Unlike an editorial board of a newspaper, the Internet's editorial policies are those of its individual users. One may write, say, or broadcast virtually anything: the users' efforts are limited only by their own ability and sense of propriety. For example, even the notorious al-Qaida website has "refused to die," 148 in spite of multi-national official and unofficial ${ }^{149}$ efforts to bring it down. The Internet, therefore, has enabled an absolute freedom of expression, a phenomenon heretofore not seen. ${ }^{150}$ The Internet has replaced a system of a few broadcasting to many and has eliminated the technological bottleneck of "spectrum scarcity" "where three national

145. Gideon Doron, former chairman of the government agency that oversaw the privatization of television and radio services in Israel, quoted in Amy Teibel, Associated Press, Israel's military takes PR battle to YouTube (Dec. 31, 2008), http://www.msnbc.msn.com/id/28450663/.

146. See Stephanie Clifford, Christian Science Paper to End Daily Print Edition, N.Y. TIMES, Oct. 28, 2008, at B8.

147. See Chicago Entrepreneur to Publish Blogs in Print Form, http://www.cbc.ca/ arts/media/story/2009/01/26/printed-blog.html (last visited January 26, 2009) ("traditional newspapers are rushing to boost their online content"); Younger, Heavy Online News Consumers are Not Newspaper Readers, Comscore.com, http:/www.comscore.com/press/release.asp?press=2109 (last visited January 26, 2009) ( demographic profile of print newspaper reader segments).

148. Michelle Delio, Al Qaeda Website Refuses to Die, WIRED, Apr. 07, 2004, http://www.wired.com/techbiz/it/news/2003/04/58356.

149. Al-Qaeda's various websites are common targets of hacker attacks. See id.

150. See supra note 88 and accompanying text.

151. See MARa EINSTEIN, MEdIA Diversity 10 (2004). 
channels and a handful of people carved out tomorrow's "breaking news." 152

With the advent of the Internet, broadcasting's insurmountable entry barriers were now gone: anyone could deliver their message in primetime. $^{153}$ Although not immediate, the changes were, nevertheless, far-reaching and fundamental. For instance, YouTube ${ }^{154}$ is a popular video hosting site and home to thousands of "channels." traditional media outlets, such as CBS, CNN, and many others, make their programming available on YouTube. ${ }^{156}$ Additionally, prominent organizations and interest groups also provide video content through YouTube. Recently, the Vatican and Tzahal (Israeli military force) joined the YouTube channel lineup. ${ }^{157}$

To broadcast on YouTube, one does not have to achieve any level of prominence: the service is open to all willing Internet participants. HotForWords is one of the many channels hosted on YouTube. ${ }^{158}$ The sole contributor of this channel, Marina Orlova, is a Russian-born etymologist. Orlova began broadcasting on YouTube in February 2007. Since that time and through January 18, 2009, her 378 "etymological" videos (short segments in which she explains the meaning of various English words), have been watched 156,624,693 times. ${ }^{159}$ Although Orlova began broadcasting two years after YouTube's launch, ${ }^{160}$ her channel currently ${ }^{161}$ ranks eighteenth on the all-time list of most-watched YouTube channels. ${ }^{162}$ To compare, the CBS channel ${ }^{163}$ on YouTube has been broadcasting since September 2006, six months longer than HotForWords. ${ }^{164}$ The CBS channel has 13,989 videos, thirty-seven times more than Orlova, and ranks seventh on the all-time view list. ${ }^{165}$ But its

152. See generally CHOMSKY DOCUMENTARY FILM, supra note 11 (describing how the front page selection remained the province of very few people).

153. See infra note 228 and accompanying text.

154. YouTube, Broadcast Yourself, www.youtube.com.

155. See YouTube Channels Page, www.youtube.com $/$ members.

156. See id.

157. See id.

158. See id.

159. 156,624,693 was the official YouTube count on January 18, 2009.

160. YouTube, Company History, http://www.youtube.com/t/about.

161. As of January 18, 2009.

162. See YouTube Channels, www.youtube.com $/$ members.

163. "CBS Corporation is a mass media company with constituent parts that reach back to the beginnings of the broadcast industry, as well as newer businesses that operate on the leading edge of the media industry." CBS Corporation, Our Company, CBS, Feb. 06, 2009, http://www.cbscorporation.com/our_company/index.php.

164. See HotForWords on YouTube, http://youtube.com/user/hotforwords; CBS on YouTube, http://youtube.com/user/cbs.

165. See YouTube Channels, www.youtube.com $/$ members. 
total views eclipse Orlova at a mere two-to-one. ${ }^{166}$ In other words, each Orlova video is watched on average 414,000 times, and each CBS video only 21,000 times.

Orlova's exposure on YouTube did not go unnoticed by other more "traditional" media outlets. Although many attribute Orlova's audience reach to her self-described "fun and playful" teaching manner, ${ }^{167}$ Orlova, nevertheless, passed the conservative scrutiny of Bill $O^{\prime}$ Reilly ${ }^{168}$ and so far appeared three times on his television show. ${ }^{169}$ In addition, Orlova hosted a bi-weekly satellite radio show on Sirius Satellite Radio. ${ }^{170}$

Every bit sensational, Orlova's experience is, nevertheless, unique even for the Internet age. On average, video blogs do not solicit this kind of overwhelming interest. ${ }^{171}$ However, one thing remains true: the World Wide Web has exponentially increased information access and idea exchange. ${ }^{172}$ The sum total of content generated by the end users is generally called "consumer-generated media" or "user-generated content."173 The effect of user-generated content has been so sweeping that even the traditional news sources such as The New York Times, $\mathrm{CNN}$, and Fox News have recognized this paradigm shift and have implemented user-generated content into their primary online offering. ${ }^{174}$ In fact, the change is every bit as significant as the invention of the

166. See id.

167. "One look at her website and it is easy to see why viewers don't mind watching her. Her site is aptly named. Marina is indeed quite attractive or "hot." Sexy Marina Orlova, Almost Too Hot for Words, Uses Her Charms to Promote Philology, Associated CONTENT, Jul.03, 2008, http://www.associatedcontent.com/article/857139/sexy_marina_ orlova_almost_too_hot_for.html?cat=15; see also Victor Sonkin, Marina Orlova Has Managed to Get Several Million People Interested in the Origins of English Words, THE Moscow TIMES, Jun. 6, 2008 ("Marina exploits her blonde-bombshell looks to the maximum: She appears in her two-minute clips scantily clad, pouting and making doe eyes. This is surely the main factor in her success. However, while the number of scantily clad girls on the Internet is limitless, not all of them put so much intellectual effort into their success.").

168. O'Reilly describes himself as "traditionalist." See Bill O'ReILly, The CULTURE WARRIOR 18 (2007). However, many associate O'Reilly's commentary with views commonly expressed by conservative Republicans. See, e.g., Conservative U.S. Anchor Now Skeptical about Bush, REUTERS, Feb. 10, 2004, http://www.signonsandiego.com/ news/nation/20040210-0550-campaign-bush-oreilly.html.

169. As of January 24th, 2009. See HotForWords, http://www.hotforwords.com/ 2008/09/23/on-the-oreilly-factor-show-3rd-appearance.

170. See HotForWords, http://www.hotforwords.com/bio.

171. See http://www.youtube.com/members.

172. See generally BECK, supra note 4 (describing information generated on the web by the end users).

173. See id. at 19 .

174. E.g., The New York Times makes use of discussion boards and blogs; CNN has launched an iReport service; Fox News has launched uReport. All of the content within these services is generated predominantly by the end-users. 
printing press centuries ago. ${ }^{175}$ The overlapping societal forces are now actively adjusting to the new playing field. ${ }^{176}$

\section{2008 Presidential Elections}

The $20^{\text {th }}$ century introduced a host of information delivery methods, and consequently, new means of "manufacturing consent." 177 The turn of the millennium presented ever-increasing efforts, both in number and in sophistication, to influence public opinion in favor of private or other interests; ${ }^{178}$ the Internet became the new battlefield. The stakes were high in the most recent presidential election, which produced a nearendless well of examples of informational abuse.

\section{Widely-recognized Bias in the Traditional Media}

The media overall, and the traditional news networks in particular, "are beneficiaries of the heightened [viewer] interest" during the presidential campaigns. ${ }^{179}$ For example, Fox News Channel's program, "The O'Reilly Factor," "the highest-rated hour on cable news, reached an average of four million viewers in September [2008]; it had two million during the same period [in 2007]." 180 This spike in viewership gives the networks a greater degree of leverage over people's opinions. At the height of the presidential campaign, Michael S. Malone of ABCnews.com wrote in a bit of refreshing honesty: "[t]he traditional media are playing a very, very dangerous game-with their readers, with the Constitution and with their own fates. The sheer bias in the print and television coverage of this election campaign is not just bewildering, but appalling."181 Mr. Malone did not stop there and stated further: "for the last couple weeks, I've begun - for the first time in my adult life- - to be embarrassed to admit what $I$ do for a living." 182 Mr. Malone is a journalist. ${ }^{183}$

175. See Jo Ann Oravec, Virtual Individuals, Virtual Groups 4 (1996) ("Both the printing press and the computer are linked historically with substantial changes in the way individuals view themselves.... [T] he advent of the computer will have at least as large and as dramatic impact on civilization as that of the printing press. ...").

176. See discussion infra Part IV and Part V.

177. See LipPMANN, supra note 54, at 248 .

178. For an excellent discussion of government's efforts to manage the news see Morse, supra note 91.

179. Brian Stelter, Fresh Face on Cable, Sharp Rise in Ratings, N.Y. Times, Oct. 20, 2008, at C1.

180. Id.

181. Michael S. Malone, Media's Presidential Bias and Decline, ABCNEWs.COM, Oct. 24, 2008, http://abcnews.go.com/Business/story?id=6099188\&page=1.

182. Id.

183. Id. 
Mr. Malone's experience is far from singular. Douglas MacKinnon, a former press secretary to Senator Bob Dole was similarly disgusted with the media "pendulum [that] had swung dangerously" left of Mr. MacKinnon's self-proclaimed "independent conservative" views. ${ }^{184}$ In his opinion, "[a]fter the presidential election is over and the dust, animosity, glee and shock settle into something manageable, the nation will need to tackle the subject of 'media bias' in a sincere and honest manner." ${ }^{185}$ The question then becomes: what is so disturbing in the media coverage that it elicits overwhelmingly-strong opinions?

"It was a lousy day to be Senator John McCain, Keith Olbermann ${ }^{186}$ informed his viewers on MSNBC"187 on October 30th, 2008. "Joe the Plumber," by then a celebrated campaign personality, did not show up at an expected rally, and Mr. Obama's surge was so strong that he was competitive even in Arizona, Senator's McCain's home state. ${ }^{188}$ But wait! On Fox News, Sean Hannity and Greta Van Susteren "told their viewers ... [that Mr. McCain got] a boost at an afternoon rally in Sandusky, Ohio, from none other than Joe the Plumber, who announced his intention to vote for 'a real American, John McCain."”189 Moreover, Mr. McCain "was gaining new ground in ever-tightening polls, despite the overwhelming bias against him in the mainstream news media; and Mr. Obama's association with a professor sympathetic to the P.L.O. was now at "the center of the election." "'190 On these two channels, the story was strikingly different; in fact, it was a "dual reality."191 Was Joe the Plumber there or was he not? Was it a tight race or a surge?

In such daily scenarios, the media's claim to impartiality is most perplexing. From the high-ground, as some type of living oracles of the First Amendment, the media fight back against any regulatory restraint. The self-imposed codes of ethics, the present regulatory regime, and the Supreme Court, all remain impotent in erecting a workable shield from wide-spread media abuse. The executive branch, meanwhile, was adding oil to the fire. According to a Congressional investigation, "[t]he White House directed officials including cabinet secretaries to appear at more

184. Douglas MacKinnon, Editorial, Media Credibility, N.Y. TIMES, Nov. 2, 2008, http://campaignstops.blogs.nytimes.com/2008/1 1/02/media-credibility/.

185. Id.

186. A news personality on MSNBC.

187. Jim Rutenberg, A Surge on One Channel, a Tight Race on Another, N.Y. TIMES, Nov. 2, 2008, at A28.

188. Id.

189. Id.

190. Id.

191. Id. 
than 300 events to help elect Republican candidates in $2006 \ldots$ often at taxpayer expense."192

2. "Sarah Palin is a Member of Alaska Independence Party"Anonymous on Al of The New York Times

Likely sensing something amiss, the Time magazine 2006 Person of the Year, or the Internet User, ${ }^{193}$ decided to take matters into its own hands and join the election battle. ${ }^{194}$ Millions of emails filled with flavorful rumors packed the inboxes of people everywhere. ${ }^{195}$ Barack Obama is a Muslim, Sarah Palin is a member of Alaska Independence Party, Joe Biden will resign in favor of Hillary Clinton, John McCain declared on television that he intentionally bombed women and children in Vietnam and so on. ${ }^{196}$ These make up just a short list of the few dozen themes. Although some of these emails sound too silly to be believable, the hyperventilating election-season media often picked up the rumors and even ran them on the front page. On September 2, 2008, Sarah Palin's purported affiliation with Alaska Independence Party was featured on page Al of The New York Times in the article "Palin Disclosures Raise Questions on Vetting."197 Rich Buhler from TruthOrFiction.com mentioned: "Most of these things, you'll never know how they started. They're brush fires."198 Passionate citizenry, as though fed up with one-way broadcasting, in an act of symbolic defiance flooded the Internet with "sensational" "forwards," with the subject line: "read this!"

The influence of these amateur "broadcasters" is hard to dispute. In attempt to negate the untruths, both campaigns set up emergency response centers to fight rumors and "rebut smears."199 Ron Bonjean, a former spokesman for House and Senate Republican leaders, said the rumors were likely spread by "random crazy folks out there who want to perpetuate rumors for the thrill of it." ${ }^{200}$ However, he left the possibility

192. Bloomberg News, Cabinet Officials Sent to Campaign at Taxpayer Expense, Report Says, N.Y. TIMES, Oct. 16, 2008, at A20.

193. See Lev Grossman, Time's Person of the Year: You, TIME, Dec. 13, 2006, http://www.time.com/time/magazine/article/0,9171,1569514,00.html.

194. Richard Allen Greene, Candidates Hit Back Hard, Fast Against Online Attacks, CNN.COM, Oct. 15, 2008, http://www.cnn.com/2008/POLITICS/10/15/internet.rumors/ index.html.

195. See id.

196. See id.

197. See Elisabeth Bumiller, Palin Disclosures Raise Questions on Vetting, N.Y.

TIMES, September 2, 2008, at Al.

198. Greene, supra note 194.

199. Id.

200. Id. 
that some of them came from "rogue political operatives." 201 All the same, the Internet has become a lively and active political highway that cannot be ignored.

Conclusion:

This section listed numerous past and recent examples of propaganda use in the United States. Over time, the delivery methods and techniques have changed, but the incentives to influence people have remained ever strong. Today, the Internet has enabled many to become "broadcasters" and "propagandists." As a result, a tremendous amount of information is created daily by Internet participants. Most of them likely take this user-generated content with a grain of salt. Moreover, many continue to rely on the decency and professionalism of the traditional media. If that is the case, this Comment has come full circle. When the freedom of expression is absolute, as in the Internet age, then a reliable source of accurate information must exist to protect the citizens from deception and lies. Historically, the role of this impartial source has been reserved for the professional media. However, numerous missteps have severely tarnished the media's reputation. Patchy, near non-existent regulatory framework is a primary contributing reason to this systemic failure.

\section{PRESENT REgUlatory FramewORK}

The examples of propaganda listed in Part III reveal an inadequate regulatory regime. At the same time, the legislature has a track record that is not entirely devoid of success. ${ }^{202}$ Congress and the FCC must erect a framework of protection, yet they must do so without rolling back the gains of progress and without infringing on the First Amendment. A top congressional priority should be the protection of "network neutrality."203 Historically, the Supreme Court has added a measure of clarity and interpretation to the succinct First Amendment. ${ }^{204}$ However, exclusive reliance on the Court in resolving the host of existent problems is misplaced within the structure of the Constitution.

\section{A. FARA: An Antiquated but Effectual Legislative Response}

The First Amendment grant of free speech serves as protection to dissenters ${ }^{205}$ and propagandists alike. ${ }^{206}$ Therefore, for the benefit of the

201. Id.

202. See discussion infra Part IV.A.

203. See discussion infra Part IV.B.3.

204. See discussion infra Part IV.C.

205. Meaning a class of free thinkers; a hallmark of a democratic society. 
dissenters, a regulatory framework forbidding political propaganda is largely non-existent. ${ }^{207}$ However, the Foreign Agents Registration Act of 1938 ("FARA") 208 is a rare example of an effectual, although somewhat imperfect and antiquated, legislative response.

FARA was passed in the wake of the ripening world conflict underscored by the rise of Nazi Germany. ${ }^{209}$ Before FARA was passed, the House of Representatives authorized the investigation of the extent, character, and object of Nazi propaganda activities in the United States; the dissemination within the United States of subversive propaganda controlled by foreign countries, attacking the American form of government; and all other questions in relation thereto that would aid Congress in any necessary remedial legislation. ${ }^{210}$ Upon the conclusion of this investigation, FARA was enacted. The ingenious bite of FARA was not to prohibit foreign political propaganda but to disclose its source. $^{211}$ Therefore, FARA did not infringe on the First Amendment freedom of speech, and unlike the Alien and Sedition Acts, ${ }^{212}$ FARA stopped short of criminalizing unwelcome expression. ${ }^{213}$ An investigative report recommending the passage of FARA contained the following lucid analogy: "Our National Food and Drug Act requires the proper labeling of various articles, and safeguards the American public in the field of health. This bill seeks only to do the same thing in a different field, that of political propaganda." 214

Accordingly, FARA requires all agents of foreign countries to register and describe the nature of their business and political activities. $^{215}$ Copies of any disseminated "political propaganda" must also be registered and submitted to the Attorney General. ${ }^{216}$ In one of the

206. The full text of the First Amendment reads: "Congress shall make no law respecting an establishment of religion, or prohibiting the free exercise thereof; or abridging the freedom of speech, or of the press; or the right of the people peaceably to assemble, and to petition the Government for a redress of grievances." U.S. CONST. amend. I.

207. See discussion infra Part IV.B and Part V. See also Angelica M. Sinopole, Comment, "No Saggy Pants": A Review of the First Amendment Issues Presented by the State's Regulation of Fashion in Public Streets, 113 PENN ST. L. REv. 329, 346 (2008) ("Messages of disagreement with the Government, expressed through acts of civil disobedience, communicate exactly the type of message the First Amendment has long been held to protect.").

208. As amended, 22 U.S.C. $\S \S 611-621$.

209. See H.R. Res. 198, 73d Cong., 2d Sess., 78 Cong. Rec. 13 (1934).

210. See id.

211. H.R. Rep. No. 1381, 75th Cong., 1st Sess. 1-2 (1937).

212. See supra note 85 and accompanying text.

213. See SMITH, supra note 89 and accompanying text.

214. H.R. Rep. No. 1381, at 3.

215. See 22 U.S.C. $\$ \S 611-621$

216. See id. 
constitutional challenges to FARA in Meese $v$. Keene, ${ }^{217}$ the Supreme Court found that FARA did not prohibit free expression. ${ }^{218}$ Instead, FARA required additional disclosure of information which would aid the recipients in forming a more accurate opinion of the message. ${ }^{219}$ If anything, the Court concluded, FARA actually fostered free speech. ${ }^{220}$

However, modern realities present a challenge to FARA's technical nuances. Today, a foreign propagandist would hardly have any difficulty evading FARA's reach. For example, the spammers of Sarah Palin is a member of Alaska Independence Party ${ }^{221}$ may reside in Canada but operate from behind an anonymous proxy server located in Bangladesh. ${ }^{222}$ It is doubtful that the spammers filled out any FARA registration forms, although they would be happy to forward their message to the Attorney General and even "carbon-copy" the entire Justice Department.

\section{B. The Federal Communications Commission and the Internet Age}

\section{Spectrum Scarcity and Content Regulation}

Since its establishment by the Communication Act of $1934,{ }^{223}$ the Federal Communications Commission ("FCC") has been charged with regulating the communications channels within the United States. ${ }^{224}$ The authority of the FCC is very broad, and the Commission can wield significant influence if it so desires. ${ }^{225}$ Traditionally, the FCC has acted as the gatekeeper of the broadcast channels (e.g., radio and television), and those who wanted to broadcast were required to serve "the public

217. Meese, 481 U.S. 465 (1987).

218. See id. at $478-82$.

219. See id.

220. See id.

221. See Greene, supra note 187 and accompanying text

222. Typically a web-server that anonymizes internet activity even if the user is surfing from a home computer.

223. As amended, 47 U.S.C. $\S 151$ ("For the purpose of regulating interstate and foreign commerce in communication by wire and radio so as to make available, so far as possible, to all the people of the United States, without discrimination on the basis of race, color, religion, national origin, or sex, a rapid, efficient, Nation-wide, and worldwide wire and radio communication service with adequate facilities at reasonable charges, for the purpose of the national defense, for the purpose of promoting safety of life and property through the use of wire and radio communications, and for the purpose of securing a more effective execution of this policy by centralizing authority heretofore granted by law to several agencies and by granting additional authority with respect to interstate and foreign commerce in wire and radio communication, there is created a commission to be known as the "Federal Communications Commission. ...").

224. See 47 U.S.C. $\$ 151$.

225. See id. 
interest, convenience, and necessity." 226 In addition to these very subjective requirements, the FCC has mounted sizeable entry barriers for prospective broadcasters. The myriad of regulatory norms, significant start-up costs, and "spectrum scarcity"227 amounted to nearly insurmountable entry barriers:

Spectrum allocation proved to be a boon for the major broadcast networks. Because of the "limited" spectrum and the need to avoid interference among stations, there could only be three networks, thus restraining competition and diversity in this market. Therefore, this choice to grant licenses and allocate spectrum established the character of the broadcast industry for the next 80 years: $A$ system of a few broadcasting to many, dominated by large corporations as the source of the transmissions. ${ }^{228}$

The preceding quote summarizes much of the popular, and probably justified, criticism towards the consequent concentration of ownership in the traditional media. ${ }^{229}$ The opponents of concentrated media ownership generally argue that commercial interests of the parent corporations jeopardize media independence. ${ }^{230}$

This discontent over ownership "monopolization" was particularly strong during the $1960 \mathrm{~s}^{231}$ In response, the FCC passed Financial Interest and Syndication Rules, also known as the "fin-syn" rules. ${ }^{232}$ The fin-syn rules sought to diversify media content by limiting the financial interest of the networks in programming. ${ }^{233}$ Thus, the fin-syn rules are an example of the FCC's influence over the content viewed by the

226. See MARa EINSTEIN, MEdia Diversity 1 (2004).

227. Id. at 10 .

228. Id. (emphasis added).

229. See, e.g., Blake D. Morant, The Endemic Reality of Media Ethics and Selfrestraint, 19 NOTRE DAME J.L. ETHICS \& PUB. POL'Y 595, 626 ("In addition to the tendency for homogeneity, monopolization of the media, particularly by large corporate entities, also leads to the perception that media content can be heavily influenced by corporate pressures, whether those pressures are direct or indirect."); see also CHOMSKY DOCUMENTARY FILM, supra note 11 (pointing out high concentration of media ownership).

230. See Morant, supra note 229, at 626.

231. See EinSTEIN, supra note 226 , at 47 .

232. 47 C.F.R. $§ 73.658$ (as amended). See also EINSTEIN, supra note 226, at 46-49.

233. See EINSTEIN, supra note 226, at 49 ("The information and data before the Commission appear to establish that network corporations, with the acquiescence of their affiliates, have adopted and pursued practices in television program procurement and production through which they have progressively achieved virtual domination of television program markets. The result is that the three national network corporation no only in large measure determine what the American people may see and hear during the hours when most American view television but also would appear to have unnecessarily and unduly foreclosed access to other sources of programs.") (quoting 1965 investigation by the FCC). 
American public. Naturally, these rules were never popular with the networks whose power and profits they abridged. ${ }^{234}$ Mt. Mansfield Television, Inc. v. FCC ${ }^{235}$ was the final legal struggle mounted by the networks before the original fin-syn rules survived judicial scrutiny on constitutionality. ${ }^{236}$ Although the fin-syn rules were eventually repealed, there are numerous examples of content regulation by the FCC. ${ }^{237}$ Whether the regulation was for better or for worse and whether it ensured First Amendment protection or abridged it remains controversial. One way or another, the FCC's rulemaking power in the television and radio age was dominant. ${ }^{238}$

\section{FCC and Government-funded Speech}

The sponsorship identification laws require broadcasters to reveal any covert sponsors of political programming. ${ }^{239}$ The origin of these laws dates back to the beginning of the last century, and when enacting them, the Congress intended "to prohibit stations from disguising advertising as program content."240 Interestingly, the sponsorship identification statutes operate similar to FARA: the underlying principle is full disclosure, which allows the public to make more accurate inferences. $^{241}$

Regarding the sponsorship provisions, the FCC was charged with protecting the integrity of the broadcasts so as to "prevent a fraud being perpetrated on the listening public by letting the public know the people with whom they are dealing." 242 Despite the general prohibition against concealed sponsorship, special interests habitually permeated the

234. See Ken Auletta, Three Blind Mice: How the TV Networks lost Their WAY 31-33 (1991).

235. Mt. Mansfield, 442 F.2d 470 (2d Cir. 1971) (upholding the fin-syn rules as constitutional).

236. See id.; EINSTEIN, supra note 226 , at 59 . The fin-syn rules were eventually amended, relaxed, and repealed by the FCC. See FCC NEWSReport No. DC 95-54,

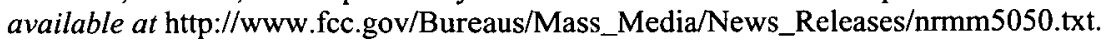

237. See, e.g., Children's Television Act of 1990. 47 U.S.C.A. $\$ 303 \mathrm{a}$ et seq. See also Red Lion Broadcasting Co. v. F.C.C., 395 U.S. 367 (1969) (FCC may, consistent with First Amendment, treat licensees given privilege of using scarce radio frequencies as proxies for entire community and as obligated to give suitable time and attention to matters of great public concern (fairness doctrine)).

238. See generally AULETTA, supra note 234 (describing the FCC's power over the television networks).

239. See, e.g., Radio Act of $1927 \S 29$.

240. Richard Kielbowicz et al., Unmasking Hidden Commercials in Broadcasting: Origins of the Sponsorship Identification Regulations, 1927-1963, 56 FED. COMM. L.J. 329, 334 (2004). See also 67 Cong. Rec. 2309 (1926) (comments of Representative Emanuel Cellar).

241. See discussion supra Part IV.A.

242. Identification on Brdcst. Station, Public Notice, 40 F.C.C. 2 (1950). 
nation's broadcasts, ${ }^{243}$ and the FCC's response was "tardy" at best. ${ }^{244} \mathrm{~A}$ void in regulation or a general disregard for law became evident again in the recent past: from 2003 through the second quarter of 2005, \$1.6 billion of taxpayers' dollars went to convince the taxpayers that their government was not amiss. ${ }^{245}$

\section{Network Neutrality: Spectrum Scarcity Revisited}

As is generally the case, the FCC's regulations lag behind the everincreasing pace of progress. ${ }^{246}$ And when the regulations are finally considered, commercial forces are at the forefront of the lobbying effort. ${ }^{247}$ However, the Internet era has presented the FCC with a set of altogether new and unique technical challenges. Until recently, few foresaw the problem of "spectrum scarcity" becoming relevant ever again, but the skyrocketing demands for data transfers threaten to bottleneck Internet channels as soon as 2010 , by some estimates. ${ }^{248}$ Consequently, many of the commercial entities whose profitability depends on a high level of data transfers seek to secure preferential network access. ${ }^{249}$ The opposition to any kind of preferential network allocation commonly rallies behind the slogan of "network neutrality.,250

[D]efined broadly, [network neutrality] is non-discriminatory interconnectedness among data communication networks that allows users to access the content and to run the services, applications, and devices of their choice. In essence, network neutrality forbids

243. See generally Kielbowicz, supra note 240 (discussing the matter at length).

244. Id. at 354 .

245. See Christopher Lee, Update: Prepackaged News, WASHINGTON POST, February 14,2006 , at A13.

246. See Kielbowicz, supra note 240 , at 345 (FCC adapting the rules to the technologies and situations of the 1950s).

247. See ANTHONy J. Nownes, Total LobBying 120 (2006) ("Many of the world's largest companies ... lobby extensively.").

248. See Sarah Reedy, Internet Could Clog Networks by 2010, Study Says, TELEPHONYONLINE, Nov. 19, 2007, http://telephonyonline.com/home/news/internet_ network_capacity_111907/.

249. For example, Comcast recently admitted that Comcast intentionally slows down Web visits during periods of high congestion. For other companies' customers who use telephony services such as Skype and Vonage this often results in a choppy phone call. However, Comcast does not intend to degrade its own Internet telephony service. See Wendy Davis, Comcast Says Slowdowns Don't Violate Net Neutrality, OnLINE MEDIA DAILY, Feb. 4, 2009, http://www.mediapost.com/publications/?fa=Articles.show Article\&art_aid=99670.

250. See Sascha D. Meinrath et al., Transcending Net Neutrality: Ten Steps Toward an Open Internet, J. INTERNET L., Dec. 2008, at 1, 11 (2008). 
preferential treatment of specific content, services, applications, and devices that can be integrated into the network infrastructure. ${ }^{251}$

The network neutrality debate is highly-heated, with just about all of the major technology companies taking a stance. ${ }^{252}$ For example, Google, eBay, and Amazon are among some of the chief proponents of network neutrality, while the traditional telecommunication companies and cable providers have mounted a successful opposition. ${ }^{253}$ So far, legislative efforts to protect network neutrality have failed. ${ }^{254}$ Tim Berners-Lee, who is commonly credited with the invention of the Internet, ${ }^{255}$ speaks empathetically on the subject:

The neutral communications medium is essential to our society. It is the basis of a fair competitive market economy. It is the basis of democracy, by which a community should decide what to do. It is the basis of science, by which humankind should decide what is true. Let us protect the neutrality of the net. ${ }^{256}$

The commonly-voiced concerns over network non-neutrality include "tier fears" or preferential access to the networks by certain companies or services. For example, today, nothing prevents a cable company from giving a video streaming service prioritized network access over Internet telephony.

Others voice even greater fears over potential content regulation: "Allowing broadband carriers to control what people see and do online would fundamentally undermine the principles that have made the Internet such a success. . . . A number of justifications have been created to support carrier control over consumer choices online; none stand up to scrutiny."257 Perhaps surprising to many, a recent precedent for such content filtering exists. In 2007, Verizon Wireless claimed a right to

251. Id.

252. See Defeat for Net Neutrality Backers, BBC, June 9, 2006, http://news.bbc.co.uk/2/hi/technology/5063072.stm.

253. See id. See also Google Net Neutrality Letter, http://www.google.com/help/ netneutrality.html.

254. See, e.g., Communications Opportunity, Promotion, and Enhancement Act of 2006, H.R. 5252, 109th Cong (2006).

255. See Charles A. Sennewald, Effective Security Management 249 (2003) (describing the web beginning with a protocol written by Berners-Lee). See generally MELISSA STEWART, TIM BERNERS-LEE: INVENTOR OF THE WORLD WIDE WEB (2001) (exploring the life and career of the person who invented HTML and shaped the way people exchange information throughout the world.).

256. Tim Berners-Lee, Net Neutrality Letter, Google.com, http://www.google.com/ help/netneutrality_letter.html.

257. Vint Cerf, Google Net Neutrality Letter, http://www.google.com/help/ netneutrality_letter.html. Vint Cerf is "Google Chief Internet Evangelist and CoDeveloper of the Internet Protocol." See id. 
block its users from accessing "controversial or unsavory" content. ${ }^{258}$ In this light, the legislature's failure to protect network neutrality is puzzling.

\section{The Supreme Court: A Sentinel of the First Amendment?}

Some argue that the Court's review, rather than legislation, should serve as a guard against foul play in the media. ${ }^{259}$ Although the author agrees that the Court has added a measure of definition to otherwise succinct Free Press and Free Speech clauses, the constitutional framework places a different burden on the judiciary. ${ }^{260}$ Moreover, the Court's response is often selective, prolonged, and limited to the cases before it. At the same time, the Court's review of relevant First Amendment jurisprudence disambiguates a great deal of complexity. Many of the principles eloquently put forward by the Court deserve commendation over the sporadic and patchy framework of the FCC regulations.

\section{Full Disclosure}

As previously argued, full disclosure generally fosters free speech. ${ }^{261}$ In Virginia State Board of Pharmacy v. Virginia Citizens Consumer Council, Inc., ${ }^{262}$ the Court stated:

[A]n alternative to... [a] highly paternalistic approach... is to assume that ... information is not in itself harmful, that people will perceive their own best interests if only they are well enough informed, and that the best means to that end is to open the channels of communication rather than to close them. ${ }^{263}$

When this proposition was made in 1976, it epitomized a true, but for its time, somewhat utopian notion. In Kleindienst v. Mandel, ${ }^{264}$ the Court explained that First Amendment issues rarely take place on a one-way street: The First Amendment gives the right to "receive information and ideas," 265 and the freedom of speech "necessarily protects the right to

258. See Adam Liptak, 'Net neutrality' War Comes to Fore, INTL. Herald TRIBUNE, September 26, 2007, available at http://www.iht.com/articles/2007/09/26/business/ verizon.php?page $=1$.

259. See, e.g., Morse, supra note 91 , at 874 ("[J]udicial intervention is necessary" to break the legislative deadlock.).

260. See U.S. ConST. art. I, III.

261. See supra text accompanying notes 211 and 213.

262. Va. State Bd., 425 U.S. 748 (1976).

263. Id. at 770 .

264. Kleindienst, 408 U.S. 753 (1972).

265. Id. at 762-63. 
receive" 266 inasmuch as it protects the right to speak. ${ }^{267}$ When the Court proffered these words, communication existed within the reality of spectrum scarcity, ${ }^{268}$ a "system of a few broadcasting to many," ${ }^{269}$ and in this way these notions were correct but, nonetheless, utopian; many desired to express opinion and be heard but few had the technical means to do so.

2. Supreme Court Puzzle: Constitutionality of Government-funded Speech

Over the years, and especially in the last three decades, the Court has had ample opportunities to consider the constitutionality of government-funded speech. The issue arose in various settings, and the Court has not been entirely consistent in its rationale. Generally, the Court analyzed government-funded speech within the framework of viewpoint discrimination. ${ }^{270}$ In this context, the so called RustRosenberger distinction ${ }^{271}$ has given lower courts and scholars alike the difficult task of interpreting an "incoherent theoretical premise." 272 In Rust v. Sullivan, ${ }^{273}$ the Court held that "viewpoint-based funding decisions can be sustained in instances in which the government is itself the speaker." 274 In Rosenberger v. Rector and Visitors of Univ. of Va., ${ }^{275}$ the Court held that viewpoint restrictions were inappropriate if the government "expend[ed] funds to encourage a diversity of views from private speakers." 276 A number of questions then arose:

Can government speak only in a formal or official capacity, explicitly and with its own coherent and clear message? Or can it speak through its agents and employees by scripting them; or through private speakers whose messages are somehow favored by subsidy or reward? Does government speak through exclusion of private speech as well as inclusion? Can its speech take the form of messages or

266. Id

267. See id.; see also Va. State Bd. of Pharmacy, 425 U.S. at 756 ("Freedom of speech presupposes a willing speaker. But where a speaker exists, as is the case here, the protection afforded is to the communication, to its source and to its recipients both.").

268. See EINSTEIN, supra note 226, at 10.

269. See id.

270. See, e.g., cases cited supra in notes 262-267 and infra in notes 271-276.

271. See Randall P. Bezanson et al., The Many Faces of Government Speech, 86 IowA L. REV. 1377, 1382 (2001).

272. See Bezanson, supra note 271.

273. Rust, 500 U.S. 173 (1991).

274. Corp. v. Velazquez, 531 U.S. 533, 541 (2001) (quoting Rosenberger, 515 U.S. at 833-34 and citing Bd. of Regents v. Southworth, 529 U.S. 217, 229, 235).

275. Rosenberger, 515 U.S. 819 (1995).

276. Id. at 834 . 
themes or attitudes attributed to, though not intended by, government? Does government speak, for example, through ordinary actions that are seen by others as expressing agreement or endorsement of some general theme? ${ }^{277}$

The author does not join the host of commentators who struggle to answer these admittedly strenuous questions. The mere amount of unresolved issues reveals a debate-scorched judicial landscape that is far from rendering any workable or definite solutions.

\section{Conclusion:}

The regulatory regime in its current form is patchy at best. Although previously the Congress and the Court delineated sound control mechanisms, few of them have been implemented. Moreover, current attempts of certain commercial forces to reintroduce "spectrum scarcity" on the Internet remain unhindered.

\section{A CALL FOR ACTION}

\section{A. The Insufficiency of Media Self-restraints}

With the advent of the Internet, freedom of expression has become more absolute than ever. ${ }^{278}$ However, freedom of expression does not equate to the freedom of speech which the First Amendment sought to protect. $^{279}$ Today, the exponentially increasing stream of information complicates truth-finding. People must work increasingly hard to determine the accuracy of received information. ${ }^{280}$ The daily volumes of

277. See Bezanson, supra note 271 , at 1382.

278. See supra note 150 and accompanying text.

279. See David A.J. Richards, Free Speech and Obscenity Law: Toward a Moral Theory of the First Amendment, 123 U. PA. L. REv. 45, 62 (1974) ("[T]he constitutionally protected liberty of free expression is the legal embodiment of a moral principle which ensures to each person the maximum equal liberty of communication compatible with a like liberty for all").

280. But cf. Abrams v. United States, 250 U.S. 616, 630 (1919) (Holmes, J., dissenting) ("[T]he ultimate good desired is better reached by free trade in ideas-that the best test of truth is the power of the thought to get itself accepted in the competition of the market, and that truth is the only ground upon which their wishes safely can be carried out. That at any rate is the theory of our Constitution. It is an experiment, as all life is an experiment. Every year if not every day we have to wager our salvation upon some prophecy based upon imperfect knowledge. While that experiment is part of our system I think that we should be eternally vigilant against attempts to check the expression of opinions that we loathe and believe to be fraught with death, unless they so imminently threaten immediate interference with the lawful and pressing purposes of the law that an immediate check is required to save the country. I wholly disagree with the argument of the Government that the First Amendment left the common law as to seditious libel in force. History seems to me against the notion. I had conceived that the United States through many years had shown its repentance for the Sedition Act of 1798, by repaying fines that it imposed" (citation omitted)). 
processed data subdue recipients' defense mechanisms against propaganda. Therefore, a reliable source of accurate information is badly needed. ${ }^{281}$ Traditionally, the professional media positioned itself as the source of accuracy. ${ }^{282}$ However, the concepts of media independence and impartiality have suffered severely, particularly in the recent past. The self-policing mechanisms of the media have failed to provide adequate protection. ${ }^{283}$

The population of the country is split on many issues. This division is a reflection of varying personal values. Naturally, people gravitate towards sources of information that reinforce these values. The news media, recognizing the pattern, often package information to attract a maximum audience. ${ }^{284}$ For example, the financial well-being of television networks hinges on a certain degree of viewership. ${ }^{285}$ Thus, a channel's profitability can be increased by including programming and opinion popular among money-spending demographics. ${ }^{286}$ Media's incentives toward profitability are strong. All the while, the profession still has the ethical obligations of truth, accuracy, and impartiality.

Hence a conflict emerges: Can monetary self-interest and ethical responsibility co-exist when, if separated, they would pursue diverging directions ? $^{287}$ This dilemma is starkly distinct from the classical market formulation promulgated by Adam Smith. ${ }^{288}$ In journalism, the vice of self-interest does not yield public benefit. The situation thus amounts to a market failure. In modern economies, failures are commonly cured through redistribution of incentives. ${ }^{289}$ A life-threatening, but curable, market failure exists in today's system of conglomerate media ownership. The skeptics have a good case: At times of high pressure, when material interests clash with ethical obligations, ethics are the underdog.

281. But cf. id.

282. E.g., Fox News' slogan "Fair and Balanced Coverage," CNN's slogan "The Most Trusted Name in News," and many other similar claims.

283. See discussion supra Parts III and IV.

284. See Christopher Gasson, Media Equities: Evaluation and Trading 148-49 (1995) (describing a strong correlation between audience share of the three major US networks and advertising revenue).

285. See id. at 147.

286. Id.

287. Sensationalism in programming arguably detracts from accuracy, and viewership, not independence or impartiality, is a common industry benchmark. Therefore, the bottom-line incentives are pecuniary and not professional.

288. See SMITH, supra note 13.

289. See e.g., CAmpbell R. MCConnell et Al., Economics: Principles, Problems, AND POLICIES 566 (2005) (stating "problem is mainly one of incentives" when considering the market failures in the context of commonly owned goods). 
Some argue from a different angle, believing that a network has only its reputation to rely on, and, therefore, the media's good name is as material as the audience share. ${ }^{290}$ In other words, the media generally has a strong interest to maintain a reputation of reliability. However, proponents of this view fail to consider the non-existence of media "Enrons." accounts time and again, none have gone under after a violation of an industry standard. ${ }^{292}$ Even more dangerously, the rules for accuracy have no bright-line definitions, and what appears "kosher" on one network is labeled "counterfeit" on the next. ${ }^{293}$ In fact, the present media framework largely resembles the American legal system of adversarial jurisprudence. The existing informational mayhem is the result of a failed system of self-restraint. ${ }^{294}$

\section{B. Failure to Pass the Federal Propaganda Prohibition Act of 2005}

Although the scope of necessary "fixes" is constantly expanding, the Congress is yet to act even within the narrow context of governmentfunded news. After the public fury over secret payments to columnists broke out in 2005, two new bills were introduced in Congress, one in the House and one in the Senate. ${ }^{295}$ The bills sought to regulate governmentfunded speech. ${ }^{296}$ Neither of the bills aimed to prohibit government expression altogether. ${ }^{297}$ The House bill, or Federal Propaganda Prohibition Act of 2005, merely sought to increase oversight over governmental spending on publicity and media relations. ${ }^{298}$

290. See Jennifer Cox, Opinion, Why Delivering the News Has Turned from an Art to a Business, THE COLBY ECHO, Feb. 27, 2008, http://media.www.colbyecho.com/ media/storage/paper1 174/news/2008/02/27/Opinions/Cracking.Down.On.The.Media-323 8788.shtml (quoting Tony Burman, former editor-in-chief of CBC news "Every news organization has only its credibility and reputation to rely on.").

291. American energy company that declared bankruptcy in 2001 after allegations of accounting fraud. As a result, Enron is often used as a metaphor for corporate fraud and dishonesty.

292. As of February 4, 2009, the author is not aware of any comparable media bankruptcies that have resulted from violations of journalistic codes of ethics.

293. See, e.g., discussion supra Part III.C.1.

294. But cf. Morant, supra note 7, at 599 ("Despite their ostensible lack of authority and susceptibility to the omnipresent pressure for ratings and profit, mechanisms such as ethical codes and other forms of self-restraint remain effective industry-wide norms and cognitive guide-posts that promote responsible journalism. Exercised conscientiously and explicitly, self restraint remains the most viable and efficient means to ensure the media's functionality within a modern democratic society.").

295. See Federal Propaganda Prohibition Act of 2005, H.R. 373, 109th Cong. (2005);

Truth in Broadcasting Act of 2005, S. 967, 109th Cong. (2005).

296. See H.R. 373 § 3(a), § 4(a)(b), § 5(a)

297. See H.R. 373; S. 967.

298. See H.R. 373. 
Additionally, the bill proposed that "public relations communications that are paid for with federally appropriated funds [should] include a prominent notice of the source of funding." 299 Although similar disclosure requirements codified in FARA had been in place for nearly seventy years, they only applied to foreign propagandists. In essence, other than the appropriation prohibitions, ${ }^{300}$ Congress has yet to adopt a coherent domestic propaganda policy; neither the House nor the Senate bill passed.

\section{Can the FCC Fill the Void?}

The Federal Propaganda Prohibition Act of 2005 was largely backed by the Democrats after a harsh public outcry against the Republican administration. ${ }^{301}$ Naturally, the Republicans did not budge at a time when the attack was largely partisan. ${ }^{302}$ Furthermore, if future legislation to curb government-funded propaganda is proposed during the times of partisan tensions, the efforts will likely be futile. To fill this void, the FCC could find an appropriate measure within its broad grant of authority and limit undisclosed government-funded speech. ${ }^{303}$ However, the FCC's head, through appointment, is often subject to the political will of the executive. For example, President Obama's nomination of Henry Rivera to head the FCC transition was received with skepticism from public interest groups and pro-consumer advocates on spectrum and broadband policies. ${ }^{304}$ At the same time, Mr. Obama's nomination of Julius Genachowski to head the FCC received a much broader support among those groups. Mr. Genachowski is a known advocate of net neutrality. ${ }^{305}$ The FCC, if it so desired, could take immediate steps to protect equal network access.

299. See id. \&5(a).

300. See Consolidated Appropriations Act, 2008, Pub. L. No.110-161, §501 (2008) ("No part of any appropriation contained in this Act shall be used for publicity or propaganda purposes not authorized by the Congress.")

Similar statutes have to be reenacted annually. Near-verbatim language has been incorporated into appropriation bills since 1951. The Federal Propaganda Prohibition Act of 2005 sought, inter alia, to eliminate annual reenaction practice by permanently codifying this prohibition. See H.R. $373 \S 4$ (a).

301. See supra note 134.

302. See id.

303. See supra note 223 (detailing the broad grant of authority to the FCC).

304. See Chris Soghoian, Obama appoints lobbyist to head FCC transition, reports say, CNET NEwS, Nov. 6, 2008, http://news.cnet.com/8301-13739_3-10084046-46.html. ("For public interest groups and technology firms hoping for pro-consumer rules on spectrum and broadband policy, this choice of someone so chummy with the established telecom interests could be bad news.").

305. See Cecilia Kang, Change Sweeping to the FCC, WASHington Post, Jan. 14, 2009 , at D01. ("The regulatory initiative is likely to shift some from incumbents ... to 


\section{What's on the Horizon?}

The Congress should pass the Federal Propaganda Prohibition Act of $2005 .^{306}$ Protecting the public from covert government propaganda should be a top priority. ${ }^{307}$ The legislature must aim for transparency and accountability. Many past examples illustrate the effectiveness of full disclosure in thwarting propaganda attempts. ${ }^{308}$ Concealment of pertinent information, such as authorship, amounts to a manner of deception, a slew of half-truths.

When it comes to the commercial media, radical changes are not necessary. However, journalistic integrity should not suffer from budgetary constraints. The present concentration of media ownership is troublesome; the networks' hunger for sensationalism in programming is detrimental to the accuracy of information. ${ }^{309}$

Modern journalism is much akin to the popular online encyclopedia, Wikipedia. ${ }^{310}$ To fight the common perception of articles' questionable reliability, Wikipedia utilizes an accuracy labeling scheme. When an article lacks reliable third-party sources, or has other deficiencies, the readers are informed beforehand. ${ }^{311}$ Tim Berners-Lee, the creator of the modern Internet, recently proposed an Internet-wide scheme for identifying the "trustworthiness" of Internet sites. ${ }^{312}$ Unlike the articles and comments in this issue of the Penn State Law Review, today's news reports rarely benefit from methodical peer editing and source-checking routines.

\section{CONCLUSION}

Broadly, this Comment examined the evolution of mass persuasion. It followed the path of liberal gains from the cradle of the printing press to the canonization of the First Amendment and beyond, into the Internet age. Historically, progress has been a catalyst for positive, liberating change, but recently, the invention of the Internet has both bolstered the

\footnotetext{
new entrants and other nontraditional telecom and media players, including Internet application/content providers" (quoting Rebecca Arbogast, analyst at the investment firm Stifel Nicolaus).

306. Federal Propaganda Prohibition Act of 2005, H.R. 373, 109th Cong. (2005).

307. See discussion supra part III.B.5.

308. See discussion supra Part IV.A.

309. See supra note 287. See generally Morant, supra note 229 (describing the media's shift towards sensationalism).

310. Wikipedia, the Free Encyclopedia, wikipedia.org.

311. See en.wikipedia.org.

312. See Pallab Ghosh, Warning sounded on web's future, BBC, 15 Sep. 2008, http://news.bbc.co.uk/2/hi/technology/7613201.stm ("Sir Tim Berners-Lee said he was increasingly worried about the way the web has been used to spread disinformation.").
} 
freedom of expression and increased the effectiveness of deceptive practices. The Comment also examined the unrestrained role of the traditional media in forming public opinion and concluded that the media's claim to independence and impartiality has been severely jeopardized by its own behavior and by commercial and governmental meddling. Unfortunately, an effective legislative response is still forthcoming. Nevertheless, such a response must emerge to protect the people from informational misuse.

The scope of any appropriate legislative action is very broad, and although this Comment uncovered many examples of malicious exploitation, the author, nevertheless, fails to recommend any universal panacea. In this regard, the Comment adds to the countless volumes of so-far futile commentary on the subject. However, an acceptable solution must exist, and those in power to effectuate a change must act.

The legislative response can be gradual, but it should be nearimmediate. As a start, Congress should adopt the Federal Propaganda Prohibition Act of 2005. By doing so, Congress will effectively articulate a much-needed check on undisclosed government-funded speech. Additionally, the legislature should codify the journalistic "standard of care." 313 The media executives' standard defense to such propositions includes an assurance that network reputation is a sufficient safeguard. If such claims are to stand scrutiny, the misuse of informational leverage must bring appropriate, behavior-modifying consequences. ${ }^{314}$

Finally, commercial forces should not define or control people's access to information via the Internet. Therefore, protecting network neutrality should become a top legislative priority. In the absence of effective Congressional action, clever and skilled propagandists will continue to exploit the vulnerable, information-overwhelmed citizenry.

313. But cf. Morant, supra note 229, at 616-18 ("Indefiniteness notwithstanding, the lack of enforcement arguably constitutes the greatest impediment to the efficacy of journalistic codes of ethics or agreements. Ethical codes have little authority unless their violation results in some sanction. In the alternative, perhaps their adoption as legal standards might imbue them with palpable authority.")

314. See id. 